\title{
A review of the family Gnaphosidae in the fauna of the Urals (Aranei), 6. Taxonomic remarks and new records, with description of a new species
}

\author{
Обзор семейства Gnaphosidae фауны Урала (Aranei), 6. \\ Таксономические заметки и новые находки, \\ с описанием нового вида
}

\author{
Sergei L. Esyunin ${ }^{1}$, Tatyana K. Tuneva ${ }^{2}$ \\ Сергей $\Lambda$. Есюнин ${ }^{1}$, Татьяна К. Тунева ${ }^{2}$
}

\author{
${ }^{1}$ Perm State University, Bukireva Street 15, Perm 614600 Russia. E-mail: Sergei.Esyunin@psu.ru \\ Пермский государственный университет, ул. Букирева 15, Пермь 614600 Россия. \\ ${ }^{2}$ Institute of Plants and Animals Ecology of the Ural branch of the RAS, 8 March Str. 202, Ekaterinburg 620144 Russia. \\ E-mail: tuneva@ipae.uran.ru \\ Институт экологии растений и животных УрО РАН, ул. 8 Марта 202, Екатеринбург 620144 Россия.
}

KEY WORDS: Araneae, new combinations, new synonyms, redescription, spider, the steppe Cis-Urals.

КЛЮЧЕВЫЕ СЛОВА: Araneae, новые комбинации, новые синонимы, степное Приуралье, пауки, переописание.

ABSTRACT. New taxonomic and faunistic data on the ground spiders of the family Gnaphosidae from the Cis-Ural steppe zone are presented based on extensive fieldwork conducted in the last decade. One species, Civizelotes aituar sp.n. $\left(\mathrm{O}^{7}\right)$, is described as new. Taxonomic problems and distribution of 11 species are discussed: Civizelotes pygmaeus (Miller, 1943), Drassodes chybyndensis Esyunin et Tuneva, 2002, D. longispinus Marusik et Logunov, 1995, D. lutescens (C.L. Koch, 1839), D. platnicki Song, Zhu et Zhang, 2004, Drassyllus sur Tuneva et Esyunin, 2003, Gnaphosa lucifuga (Walckenaer, 1802), G. pilosa Saveljeva, 1972, Trachyzelotes manytchensis Ponomarev et Tsvetkov, 2006, Urozelotes trifidus Tuneva, 2003 and Zelotes rufi Efimik, 1997. All the studied species are diagnosed and illustrated. Two species names are synonymized: Drassodes natali Esyunin et Tuneva, 2002 syn.n. with D. platnicki Song, Zhu et Zhang, 2004 (the replacement name for $D$. lesserti Schenkel, 1936); and Zelotes fallax Tuneva et Esyunin, 2003 syn.n. with Z. rufi Efimik, 1997. Six species - Gnaphosa mandschurica Schenkel, 1963, Haplodrassus bohemicus Miller et Buchar, 1977, H. orientalis (L. Koch, 1866), Micaria bosmansi Kovblyuk et Nadolny, 2008, Parasyrisca arrabonica Szinetár et Eichardt, 2009 and Talanites mikhailovi Platnick et Ovtsharenko, 1991 are reported from Orenburg Area for the first time; one previously recorded species — Gnaphosa betpaki Ovtsharenko, Platnick et Song, 1992 - is excluded from the regional list.

How to cite this article: Esyunin S.L., Tuneva T.K. 2020. A review of the family Gnaphosidae in the fauna of the Urals (Aranei), 6. Taxonomic remarks and new records, with description of a new species // Arthropoda Selecta. Vol.29. No.1. P.103-120. doi: 10.15298/ arthsel. 29.1.09

РЕЗЮМЕ. Представлены новые таксономические и фаунистические данные о наземных пауках семейств Gnaphosidae из степной зоны Предуралья, полученные в результате обширных полевых работ, проведенных в последнее десятилетие. Один вид, Civizelotes aituar sp.n. $\left(\bigcirc^{7}\right)$, описан как новый. Обсуждаются таксономические проблемы и распространение 11 видов: Civizelotes pygmaeus (Miller, 1943), Drassodes chybyndensis Esyunin et Tuneva, 2002, D. longispinus Marusik et Logunov, 1995, D. lutescens (C.L. Koch, 1839), D. platnicki Song, Zhu et Zhang, 2004, Drassyllus sur Tuneva et Esyunin, 2003, Gnaphosa lucifuga (Walckenaer, 1802), G. pilosa Saveljeva, 1972, Trachyzelotes manytchensis Ponomarev et Tsvetkov, 2006, Urozelotes trifidus Tuneva, 2003 и Zelotes rufi Efimik, 1997. Синонимизированы два вида: Drassodes natali Esyunin et Tuneva, 2002 syn.n. c D. platnicki Song, Zhu et Zhang, 2004 (замещающее имя для D. lesserti Schenkel, 1936); и Zelotes fallax Tuneva et Esyunin, 2003 syn.n. с Z. rufi Efimik, 1997. Диагностические признаки всех видов проиллюстрированы. Шесть видов, Gnaphosa mandschurica Schenkel, 1963, Haplodrassus bohemicus Miller et Buchar, 1977, H. orientalis (L. Koch, 1866), Micaria bosmansi Kovblyuk et Nadolny, 2008, Parasyrisca arrabonica Szinetár et Eichardt, 2009 и Talanites mikhailovi Platnick et Ovtsharenko, 1991, впервые зарегистрированы в фауне Оренбургской области; один ранее отмечавшийся вид - Gnaphosa 
betpaki Ovtsharenko, Platnick et Song, 1992 — исключен из регионального списка.

\section{Introduction}

The present paper is a continuation of our earlier studies on the Ural gnaphosid fauna [Esyunin, Tuneva, 2002; Tuneva, Esyunin, 2002, 2003a, b; Tuneva, 2007]. At the moment, 91 gnaphosid species are known from the Urals [Tuneva, Esyunin, 2009], of which the majority (64 species; 70\%) are recorded from the Cis-Ural steppe zone.

During the past decade, since our last publication on this topic, numerous materials have been collected from various localities of the steppe zone of Orenburg Area (the southern Cis-Urals). A number of species that are new to the regional fauna have been found in this material. Yet, the species which were described from singletons are now represented by long series. This allowed us to assess a variation of their morphological characters and provide updated diagnoses.

The aims of this paper are as follows: (1) to describe a new Civizelotes species, (2) to clarify descriptions of some poorly known gnaphosid species, (3) to propose and justify two new synonyms, (4) to discuss the most interesting faunistic records, and (5) to correct regional mistaken identifications.

\section{Material and methods}

This paper is based both on newly collected gnaphosid specimens and on museum collections. The studied material has been deposited in or borrowed from the following museums (the curator name is given in parentheses): ISEA Institute of Systematics and Ecology of Animals, Novosibirsk, Russia (G.N. Azarkina); MMUE - The Manchester Museum, University of Manchester, UK (D.V. Logunov); PSU - Zoological Museum of the Perm State University, Perm, Russia (S.L. Esyunin); ZMMU — Zoological Museum of the Moscow State University, Moscow, Russia (K.G. Mikhailov).

SEM micrographs were made by means of Hitachi TM3000 SEM microscope with BSE (back-scattered electrons) at the Perm State University. Colour digital images was taken manually by using Olympus OMD EM-10 digital camera with Panasonic Lumix H-H025 25 mm f/1.7 lens mounted on Zeiss microscope. Digital images were then processed by using the Photoshop CS6 image stacking software.

The terminology of the gnaphosid copulatory organs morphology follows Platnick, Shadab [1976, 1982, 1983] for the genera Drassodes, Drassylus and Zelotes accordingly, and Kovblyuk [2005] for the genus Gnaphosa.

Collector's names of those who collected five or more samples are abbreviated as follows: ESL - S.L. Esyunin, FGS - G.Sh. Farzalieva, GAV - A.V. Gromov, KVO V.O. Koz'minykh, LDV - D.V. Logunov, SSS - S.S Sokolova, TTK - T.K. Tuneva, ZVK - V.K. Zinchenko.

The following abbreviations are used in the text: AER anterior eye row; ALE - anterior lateral eye; AME anterior median eye; $\mathrm{d}$ - dorsal; PER - posterior eye row; $\mathrm{pl}$ - prolateral; PLE — posterior lateral eye; PME - posterior median eye; rl - retrolateral; RTA - retrolateral tibial apophysis; v - ventral. The leg measurements are given in the following order: total length (femur, patella+tibia, metatarsus, tarsus). All measurements are given in millimeters.

\section{Survey of species}

\section{Civizelotes aituar sp.n.} Figs 1, 2.

TYPE: Holotype $0^{T}$ (ZMMU) from Russia, Orenburg Area, Kuvandyk Distr., nr. Aituar Vil. (51 $\left.07^{\circ} \mathrm{N}, 57^{\circ} 39^{\prime} \mathrm{E}\right)$, 'Aituarskaya Steppe' division of Orenburg Reserve, multiherbaceous steppe, 27.V-7.VI.1996, N.S. Mazura.

ETYMOLOGY. The species name is a noun in apposition referring to the type locality.

DIAGNOSIS. Civizelotes aituar sp.n. belongs to the gracilis species group (sensu Senglet, 2012) and, by the looped embolus with a membranous flop and lateral lamellar median apophysis, is most similar to C. gracilis (Canestrini, 1868) and C. pygmaeus (Miller, 1943) (see Figs 3-4; Miller [1967: pl. 4, figs 1-4, 5-8]; Grimm [1985: figs 232, 233]). The new species can easily be distinguished from them by (1) the absence both of the denticle on the embolic base and of the embolar projection (with the embolic projection in $C$. gracilis and C. pygmaeus; see Figs 3, 5 and fig. 233b in Grimm [1985]), and (2) by the broad median apophysis with its outer part being curved at the right angle (MA; Fig. 1), compared to the narrow median apophysis with the free narrow external part directed backward in C. pygmaeus and C. gracilis (see Figs 3, 5 and figs 4, 7 in Miller [1967, Pl. 4]). C. aituar sp.n. is less similar to Marjanus platnicki (Zhang, Song et Zhu, 2001), from which is can easily be distinguished by the shorter and thicker RTA (long, thin and pointed in M. platnicki [Chatzaki, 2018: figs 6, 11, 12]) and the longitudinal median apophysis (not transverse, as in $M$. platnicki [Chatzaki, 2018: fig 11]).

DESCRIPTION. Male. Small spider, total length 3.3. Carapace length 1.4, width 1.1; shiny yellow-brown, with light sparse setae. Eyes field blackish, AER width 0.28 , PER width 0.31 . Medial eyes field trapezoid: length 0.18 , width 0.14 anteriorly and 0.18 posteriorly. Eye sizes: $\mathrm{AME}=\mathrm{ALE}=$ PLE 0.07, PME (oval) $0.06 \times 0.08$. Eyes of the anterior row touch each other; eyes of the posterior row are slightly separated from each other: PLE-PME 0.03, PME-PME 0.01. All eyes light except for black AMEs. AER straight, PER slightly procurved. Chelicerae yellow, with 4 long setae along the inner side of basal segment, and numerous setae on the inner surface. Cheliceral furrow with some very small teeth and a row of setae on the promargin, but with no teeth on retromargin. Labium and maxillae yellow, with a white tip. Sternum yellow, with grey radial lines. Legs coloration: femur yellow; other segments greyish yellow. Leg formula is IV $>$ I $>$ II $>$ III. Leg measurements: I $3.56(0.99,1.39,0.62$, $0.56)$, II $3.05(0.85,1.13,0.57,0.49)$, III $2.56(0.69,0.87$, $0.56,0.45)$, IV $4.21(1.12,1.55,1.01,0.53)$. Leg spination: Femur I and II d1-1-0; III d1-1-0, pl 0-1-1, rl 0-1-1; IV d11-1, pl 0-0-1, rl 0-0-1; Tibia I and II without distinguish spines; III pl 1-0-1, rl 0-1-1, v 2-2-2; IV pl 1-0-1, rl 0-2-0, v 2-2-2; Metatarsi I and II without distinguish spines; III pl 0$2-2$, rl 1-1-2, v 2-0-0; IV pl 1-2-2, rl 1-2-1, v 2-0-0. Spines of femur I thin, resembling long bristles; those of femurs III and IV thick and long. Metatarsi III and IV with a preening comb. Metatarsus and tarsus I and II with numerous setae 

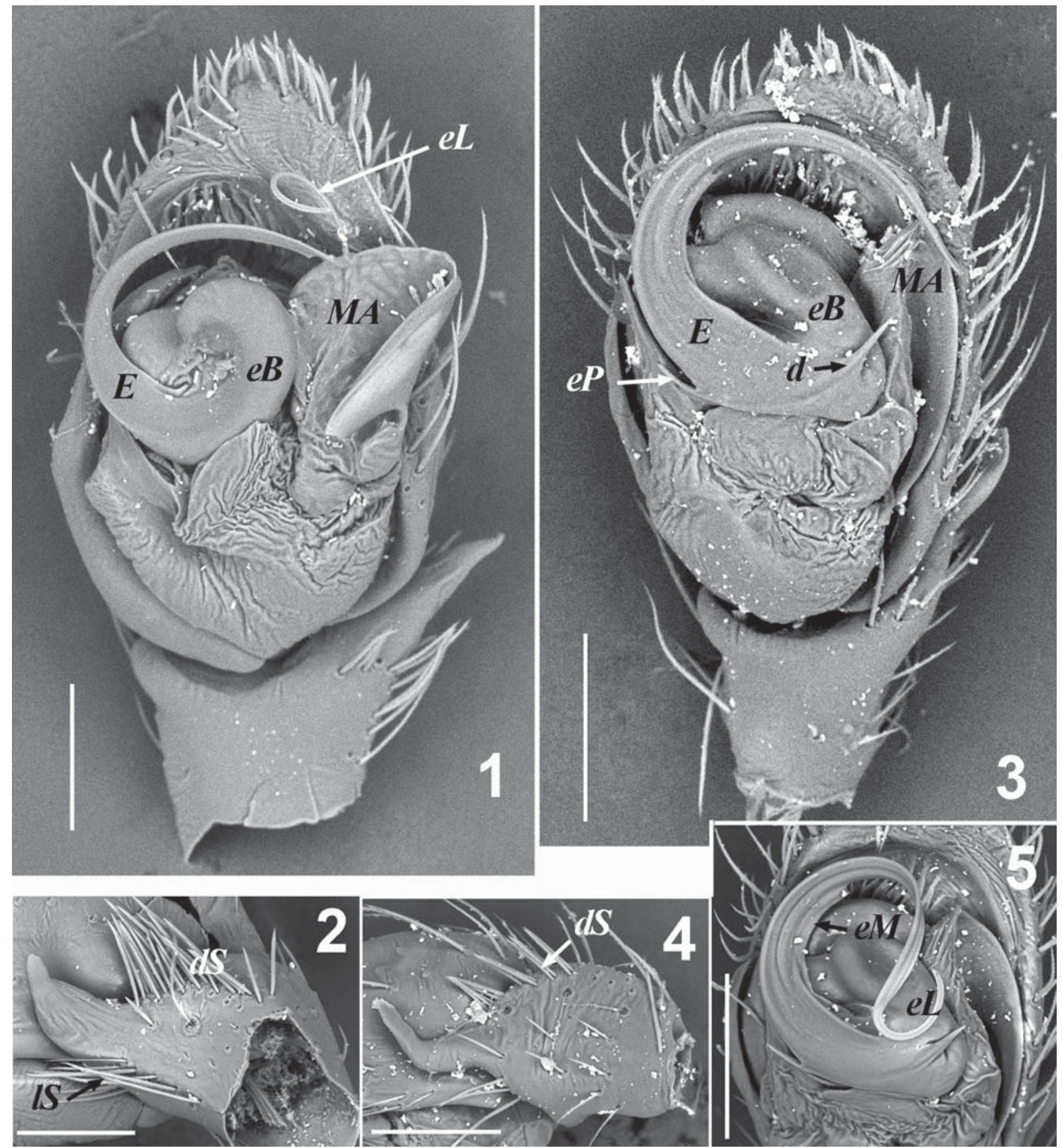

Figs 1-5. Civizelotes aituar sp.n. (1-2) and C. pygmaeus (Miller, 1943) (3-5), scanning electron micrographs: 1, 3 - male palp, ventral view, 2, 4 - tibia of male palp, lateral view, 5 - bulbus, ventral view. Abbreviations: $d$ - denticle of the embolic base; $d S-$ dorsal row of spines; $E$ - embolus; $e B$ - embolic base; $e L$ - loop of embolic tip; $e M$ - membrane of embolus; $e P$ - embolic projection; $I S$ - retrolateral row of spines; $M A$ - median apophysis. Scale bars: $0.1 \mathrm{~mm}$

Pис. 1-5. Civizelotes aituar sp.n. (1-2) и C. pygmaeus (Miller, 1943) (3-5), сканирующие электронные микрофотографии: 1, 3 пальпа, снизу, 2, 4 - голень пальпа самца, сбоку, 5 - бульбус, снизу. Сокращения: $d$ - зубчик основание эмболюса; $d S-$ дорсальный ряд щетинок; $E$ - эмболюс; $e B$ - основание эмболюса; $e L-$ петля вершины эмболюса; $e M$ - мембрана эмболюса; $e P$ - отросток эмболюса; $l S$ - латеральный ряд щетинок; $M A$ - срединный отросток. Масштаб: 0,1 мм.

and hairs protruding in all directions. Abdomen length 1.9, width 1.1; grey-yellow; book lung operculum yellow. Scutum triangular, covering one-third of the abdominal dorsal surface. Anterior lateral spinnerets cylindrical, separated from each other by their diameter. PALP. Embolic base $(e B)$ is situated at the apical-prolateral part of the tegulum (Fig. 1).
Embolus originates from the posterior part of embolic base, making a semicircle, turning dorsally and forming a loop (eL, Fig. 1). Its semicircle part with a membrane, broadening at its base and evenly narrowing to its apex. Median apophysis large lamellar, situated retrolaterally (MA, Fig. 1); its outer part is curved at right angles to the base. Palpal femur 
with two (d0-1-1) and patella with one (d0-0-1) dorsal spines. Palpal tibia with dorsal $(d S)$ and retrolateral $(l S)$ rows of spines (Fig. 2). RTA is directed laterad and frontwards; its tip curved dorsally (Fig. 2).

Female unknown.

DISTRIBUTION. The type locality only.

\section{Civizelotes pygmaeus (Miller, 1943) Figs 3-5.}

Zelotes pygmaeus: Miller, 1943: 16, pl. I, figs 7-12 ( $\left.\sigma^{7}+\right)$. Zelotes pygmaeus: Miller, 1967: 269, pl. IV, figs 5-8, pl. VII, fig. $8\left(\sigma^{\top}+\right)$.

Zelotes pygmaeus: Grimm, 1985: 284, figs 232, 236-237 ( $\left.0^{7}+\right)$ Zelotes gracilis (nec Canestrini): Thaler, Noflatscher, 1990: 176 , figs $35-36\left(\sigma^{7}\right)$

For a complete list of the taxonomic references see WSC [2018]

MATERIAL. Russia, Orenburg Area: $5 \sigma^{7} \sigma^{7}, 1$ (PSU-394), Kuvandyk Distr. 'Aituarskaya Steppe' division of Orenburg Reserve $\left(51^{\circ} 06^{\prime} 47^{\prime \prime} \mathrm{N}, 57^{\circ} 39^{\prime} 25^{\prime \prime} \mathrm{E}\right)$, steppe, 17.V-1.VI.1996, Mazura N.S., 18-23.V.2017, ESL; 54 ठ' $\sigma^{\top}, 9$ 우 (PSU-1182), Sol-Iletsk Distr., c. $10 \mathrm{~km} \mathrm{~W}$ of Troitsk Vil., Chybynda (=Shybynda) gully $\left(50^{\circ} 40^{\prime} 52^{\prime \prime} \mathrm{N}, 54^{\circ} 27^{\prime} 28^{\prime \prime} \mathrm{E}\right)$, chalk slope, bank of a man-made lake in steppe, 5-12.VI.2000, ESL; $2 \sigma^{7} \sigma^{7}, 2$ of (PSU-3738), same locality, steppe of Stipa and another herbs, 7-14.VI.2003, TTK; 1 $\sigma^{7}, 1$ (PSU-3739), Sol-Iletsk Distr., Novoiletsk Vil., 5-15.VI.2003, TTK; 1 ○ (PSU-3189), Svetlyi Vil., Shalkar-Igiz-Kara Lake, saline land, 10-16.VI.2002, TTK; $1 \sigma^{\top}$ (PSU-4294), Orenburg Distr., c. 3 $\mathrm{km}$ NE of Pervomajskij Vil., Donguzskaya Steppe $\left(51^{\circ} 33^{\prime} 14^{\prime \prime} \mathrm{N}\right.$, $55^{\circ} 01^{\prime} 37^{\prime \prime} \mathrm{E}$ ), steppe, 11-20.V.2007, KVO; 3 O $^{7} \sigma^{7}$ (PSU-7616), Svetlyi Distr., 'Ashchisayskaya Steppe' division of Orenburg Reserve $\left(50^{\circ} 57^{\prime} 38^{\prime \prime} \mathrm{N}, 61^{\circ} 12^{\prime} 44^{\prime \prime} \mathrm{E}\right)$, steppe with Artemisia and other herbs, VI.2015, SSS; $5 \sigma^{\top} \sigma^{\top}, 5$ 우 (PSU-7615), same locality, sandy drift near steppe pond, steppe with Spirea, VI.2016, ESL; 5 $\sigma^{7} \sigma^{7}, 1 \bigcirc$ (MMUE), same locality, rubbly steppe, saline land, VI.2016, ESL. Chelyabinsk Area: $9 \sigma^{\top} \sigma^{\top}, 4$ 4 + (PSU-3699), Troitsk Distr., Uj River, stony steppe with shrub, 8.VII.1994, ESL. Bashkortostan: 1 + (PSU-6957), Meleuz Distr., Syrtlanovo Vil., Festuca-Stipa steppe, 22.VII-1.VIII.1990, V.E. Efimik.

REMARKS. C. pygmaeus was first described from the vicinity of Mohelno Town in Czech Republic, where it inhabits steppes on the serpentinite [Miller, 1943]. Miller mentioned that the male of $C$. pygmaeus is extremely close to that of $C$. gracilis, from which it can be distinguished by the following characters: (1) the longer RTA ("Durch die Größe und durch den Bau der Kopulationsorgane steht diese Spinne am nächsten der Art Zelotes gracilis ... Die Tibialapophyse ist länger und hat eine andere Form" [Miller, 1943: p. 17]), (2) the presence of a large denticle at the embolic base (d, Fig. 3;"s" - "Zahn der basalen Embolusplatte" in Miller [1967] and " $x_{1}$ " in Grimm [1985]), compared to the poorly discernible denticle [Miller, 1967, table IV, fig. 4 and unnumbered fig. at the bottom-middle of table IV] or none [Grimm, 1985, fig. 233b] in C. gracilis, (3) the short and thin embolar projection ( $e P$, Fig. 3; "n - basaler Zahn (Nebenarm) des Embolus" in Miller [1967] and " $\mathrm{x}_{2}$ " in Grimm [1985]), compared to the long and rounded embolic projection in C. gracilis [Miller, 1967, table IV, fig. 4 and unnumbered fig. at the bottom-middle of table IV; Grimm, 1985, fig. 233b].

Thaler \& Noflatscher [1990] provisionally identified and illustrated males from South Tyrol as Zelotes gracilis. Maria Chatzaki, who re-examined the material presented in their paper, confirmed that "the material recorded in that paper clearly belongs to C. gracilis" (Chatzaki, pers. comm., 10 August 2017). The problem is that figs 35-36 in Thaler \& Noflatscher [1990] undoubtedly show a different species, viz., C. pygmaeus. All the diagnostic characters that are typical of C. pygmaeus are illustrated in the cited figures: (1) RTA bent upward (fig. 36 in Thaler \& Noflatscher [1990]), (2) a distinguishable denticle at the embolic base ("s" in fig. 35 in Thaler \& Noflatscher [1990]), and (3) the short pointed embolic projection (" $n$ " in fig. 35 in Thaler \& Noflatscher [1990]).

DISTRIBUTION. West-Palaearctic steppe range: from Italy and Austria [Nentwig et al., 2018] to East Kazakhstan Area [Eskov, Marusik, 1995] and the Altai [Azarkina, Trilikauskas, 2013].

\section{Drassodes chybyndensis Esyunin et Tuneva, 2002} Figs 6, 7.

Drassodes lapidosus (nec Walckenaer): $\mathrm{Hu}, \mathrm{Wu}, 1989: 257$, fig. 210.1-6 ( $\sigma^{\top}+$, misidentification).

Drassodes chybyndensis Esyunin et Tuneva, 2002: 169, figs 1-7 ( $\left.\mathrm{O}^{\top}+\right)$.

Drassodes chybyndensis: Marusik, Logunov, 2011: 60, figs 19-26 (o'o).

Drassodes chybyndensis: Namaghi et al., 2016: 18, fig. 1a-b, $2 \mathrm{a}-\mathrm{d}\left(\mathrm{O}^{\top}+\right)$

MATERIAL. Russia, Orenburg Area: Paratype $1 \sigma^{7}$ (PSU1413), Sol-Iletsk Distr., c. $10 \mathrm{~km} \mathrm{~W}$ of Troitsk Vil., Chybynda (=Shybynda) gully $\left(50^{\circ} 40^{\prime} 52^{\prime \prime} \mathrm{N}, 54^{\circ} 27^{\prime} 28^{\prime \prime} \mathrm{E}\right)$, shrub steppe on chalky rock, 5-12.VI.2000, ESL; $10^{7}$ (PSU-3752), same locality, steppe, 14.VI.2003, TTK; $10^{7}$ (PSU-3753), Kuvandyk Distr., mouth of Alimbet River $\left(51^{\circ} 04^{\prime} 5^{\prime \prime} \mathrm{N}, 57^{\circ} 37^{\prime} 4^{\prime \prime} \mathrm{E}\right)$, steppe, 8.V.2003, TTK; $1 \sigma^{7}$ (PSU-6493), Svetliy Distr., c. $12 \mathrm{~km} \mathrm{~S}$ of Yasnyi Vil., steppe, under stone, 7.V.2015, ESL; $3 \sigma^{7} \sigma^{7}$ (PSU-6494), same distr., Boevaya Gora, stony \& shrub steppes, 2-10.V.2015, ESL; $4 \sigma^{7} \sigma^{7}$ (PSU-7611), same distr., 'Ashchisayskaya Steppe' division of Orenburg Reserve $\left(50^{\circ} 57^{\prime} 38^{\prime \prime} \mathrm{N}, 61^{\circ} 12^{\prime} 44^{\prime \prime} \mathrm{E}\right)$, stony steppe, 6.V.2015, ESL; $3 \sigma^{7} \sigma^{\top}$ (MMUE), same locality, stony steppe, 6.V.2015, S.V. Dedyukhin. Kazakhstan, South Kazakhstan Area: 19 (PSU$5985)$, c. $40 \mathrm{~km} \mathrm{~N}$ of Talap Vil., Karatau Mt. Range, bank of Besaryk River, $43^{\circ} 45.748^{\prime} \mathrm{N}, 67^{\circ} 49.085^{\prime} \mathrm{E}$, 6.V.2010, TTK; 1 \% (PSU-6362), c. 40 km NE of Sholakk-Kurgan, Karatau Mt. Range $\left(43^{\circ} 41^{\prime} \mathrm{N}, 68^{\circ} 49^{\prime} \mathrm{E}\right), 860 \mathrm{~m}$ a.s.1., 3.V.2012, A.V. Ivanov. EastKazakhstan Area: 1 (ISEA, 001.7932), western branch of Narymskiy Mt. Range, nr. Aktobe, desert, 3-4.V.1999, I. Lyubarskiy, A. Korolyuk; 1 (ISEA, 001.7947), South Altai Mt. Range, Markakol Lake, nr. Urumkhalka, $\left(48^{\circ} 47^{\prime} \mathrm{N}, 8^{\circ} 01^{\prime} \mathrm{E}\right)$, 10.VI.1998, GAV; 1 $\sigma^{7}$ (ISEA, 001.7934), Dzhungar Alatau Mt. Range, c. 4 km NW of

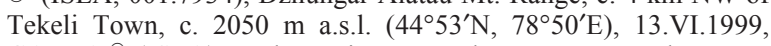
GAV; 1 ㅇ (ISEA), Tarbagatai Mts, north-western Manrak Range, Tayzhuzgen River, 6.IX.1997, R. Dudko, ZVK; 1 क (ISEA), Urzhar Distr., nr. Kabanbay Vil. $\left(46^{\circ} 04^{\prime} \mathrm{N} 82^{\circ} 05^{\prime} \mathrm{E}\right)$, Aranzan-Tay Mt., Stipa-Artemisia steppe, 8.V.2002, I.I. Lyubechanskii; $1 \sigma^{\top}$ (ISEA), western branch of Narymskiy Mt. Range, c. $15 \mathrm{~km}$ SE of Slavyanka Vil., petrophytous steppe, 6.V.1999, I. Smelyanskiy. Kyrgyzstan: 2 90 (ISEA, 001.7944), Sarykamysh Mt. Range, c. 8 km SW of Kyzyloy, 2500-2800 m a.s.1., 16-18.VIII.1998, GAV; 1 ○', 1 우 (ISEA, 001.7939), western end of Issyk-Kul Lake, c. $5 \mathrm{~km} \mathrm{SW}$ of Balykchy (=Rybachye) Town $\left(42^{\circ} 24^{\prime} \mathrm{N}, 7^{\circ} 06^{\prime} \mathrm{E}\right), 25 . \mathrm{VI} .1999$, GAV; 2 of (ISEA, 001.7943), western end of Issyk-Kul Lake, c. 2 km SW of Balykchy (=Rybachye) Town $\left(42^{\circ} 27^{\prime \prime} \mathrm{N}, 76^{\circ} 08^{\prime \prime} \mathrm{E}\right)$, 24.VI.1999, GAV. Tajikistan: 1 (ISEA, 001.7897), Tavildara Distr., flood-plain of Balangu River, northern branch of Khazratishokh Mt. Range, $1880-1975 \mathrm{~m}$ a.s.1. $\left(38.65^{\circ} \mathrm{N}, 70.52^{\circ} \mathrm{E}\right)$, pitfall traps, 8-15.V.2016, ZVK; 1 O' (ISEA, 001.7881), same locality, pitfall traps, 15-21.V.2016, ZVK. Turkmenistan: $1 \sigma^{7}$ (ISEA), c. $30 \mathrm{~km} \mathrm{SE}$ of Shakhrisabz $\left(39^{\circ} 03^{\prime} \mathrm{N}, 66^{\circ} 50^{\prime} \mathrm{E}\right), 1200-1300 \mathrm{~m}$ a.s.l., 25.IV.1993, LDV; $1 \sigma^{7}$ (ISEA), western Kichitang, c. 5 km SE Bäherden ( $\left.38^{\circ} 25^{\prime} \mathrm{N}, 5^{\circ} 26^{\prime} \mathrm{E}\right), 5-11 . I V .1991$, V.V. Dubatolov, ZVK.

REMARKS. D. chybyndensis was described from the south steppe zone, from the territory situated at the border between Orenburg Area of Russia and Aktyubinsk Area of Kazakhstan. Later, Marusik \& Logunov [2011] recorded 

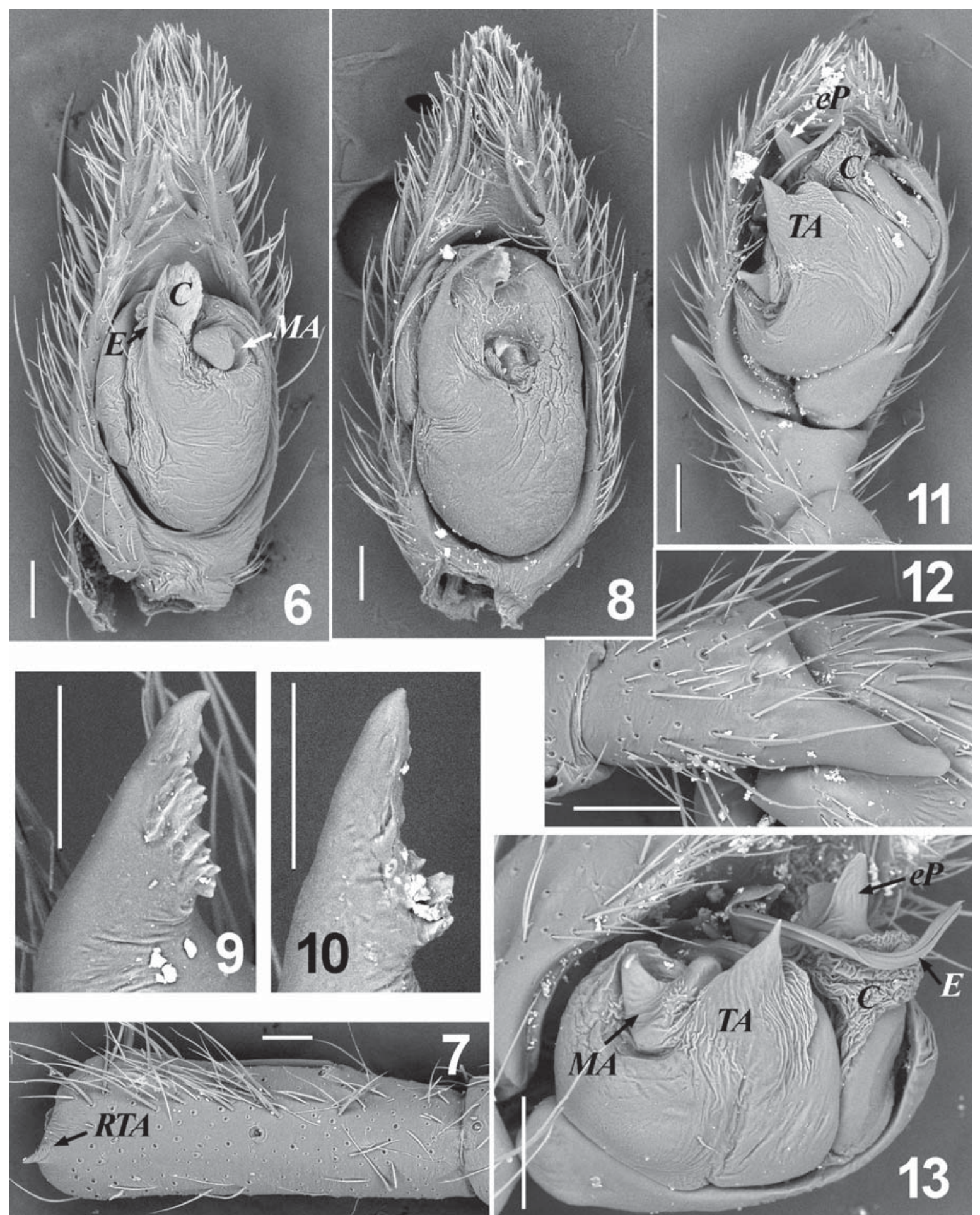

Figs 6-13. Drassodes chybyndensis Esyunin et Tuneva, 2002 (6-7), D. platnicki Song, Zhu et Zhang, 2004 (8-10) and Drassyllus sur Tuneva et Esyunin, 2003 (11-13), scanning electron micrographs: 6, 8, 11 - male palp, ventral view, 7, 12 - tibia of male palp, lateral view, 9, 10 - tip of retrolateral tibial apophysis (RTA), 13 - bulbus, apical view. Abbreviations: $C$ - conductor; $E-$ embolus; $e P-$ embolar projection; $M A$ - median apophysis; $T A$ - terminal apophysis. Scale bars: $0.1 \mathrm{~mm}$.

Рис. 6-13. Drassodes chybyndensis Esyunin et Tuneva, 2002 (6-7), D. platnicki Song, Zhu et Zhang, 2004 (8-10) и Drassyllus sur Tuneva et Esyunin, 2003 (11-13), сканирующие электронные микрофотографии: 6, 8, 11 - пальпа, снизу; 7, 12 - голень пальпа самца, сбоку; 9, 10 - вершина ретролатерального отростка голени (RTA), 13 - бульбус, спереди. Сокращения: $C$ кондуктор; $E$ - эмболюс; $e P$ - отросток основания эмболюса; $M A$ - срединный отросток; $T A$ - терминальный отросток. Масштаб: 0,1 мм. 
this species from East Kazakhstan. Hu \& Wu [1989] recorded and illustrated D. lapidosus (Walckenaer, 1802) from the neighboring Chinese Province of Xinjiang. The specimens of Drassodes aff. chybyndensis from central Xinjiang studied by Marusik et al. [2007] slightly differ from those of $D$. chybyndensis from East Kazakhstan, as follows: the longer RTA and slightly different proportions of the epigyne. It is likely that these differences reflect just an intra-specific variation rather than species differences. Thus, the specimens of D. lapidosus recorded from Xinjiang seemed to have been misidentified and some/many records of this species by $\mathrm{Hu} \& \mathrm{Wu}$ [1989: fig. 213, Map] should actually be referred to $D$. chybyndensis.

DISTRIBUTION. Central ancient-Mediterranean steppedesert range: from the western shore of Caspian Sea and Iran to NW China.

South-European Russia: Dagestan, Krasnodar Territory, Astrakhan and Orenburg Areas [Ponomarev, Mikhailov, 2007: sub D. lacertosus; Ponomarev et al., 2011: sub D. lacertosus; Abdurakhmanov et al., 2012; Ponomarev, Dvadnenko, 2013; Ponomarev, Abdurakhmanov, 2014]. Kazakhstan: Mangystau, Kostanay, South Kazakhstan and East Kazakhstan Areas [Marusik, Logunov, 2011; Ponomarev, Abdurakhmanov, 2014; Ponomarev, Bragina, 2014; present data]. Turkmenistan, Tajikistan and Kyrgyzstan [present data]. Iran: Razavi Khorasan Province [Namaghi et al., 2016]. North-West China: Xinjiang [Hu, Wu, 1989: sub D. lapidosus; Marusik et al., 2007: sub D. aff. chybyndensis].

Drassodes longispinus Marusik et Logunov, 1995 Figs 14, 15.

Drassodes longispinus Marusik, Logunov, 1995: 185, figs 26$33\left(\sigma^{\top}+\right)$.

Drassodes serratidens: $\mathrm{Hu}, \mathrm{Wu}, 1989,258$, fig. 211.3 (О) only; Fig. 211.1-2; 우 — ?. platnicki Song, Zhu et Zhang, 2004). $\left(\sigma^{\top}+\right)$.

Drassodes longispinus: Song et al., 2004, 62, fig. 32A-F

Drassodes longispinus: Zhu, Zhang, 2011, 383, fig. 274A-F $\left(\bigcirc^{7}+\right)$ (copied from Song et al. [2004]).

Drassodes lesserti: Esyunin, Tuneva, 2002, 172, figs 60-62 ( + ; misidentification).

Drassodes platnicki: Tuneva, Esyunin, 2012, 374, figs 1-3 (웅 misidentification).

MATERIAL. Russia, Orenburg Area: Paratype of D. natali 1 $\sigma^{7}$ (PSU-1415), Sol-Iletsk Distr., c. $10 \mathrm{~km} \mathrm{~W}$ of Troitsk Vil., Chybynda (=Shybynda) gully $\left(50^{\circ} 40^{\prime} 52^{\prime \prime} \mathrm{N}, 54^{\circ} 27^{\prime} 28^{\prime \prime} \mathrm{E}\right)$, wormwood (Artemisia) steppe, 6-12.VI.2000, ESL; 2 우 (PSU-1928: as D. lesserti), Sol-Iletsk Distr., c. $10 \mathrm{~km} \mathrm{~W}$ of Troitsk Vil., Chybynda (=Shybynda) gully $50^{\circ} 40^{\prime} 52^{\prime \prime} \mathrm{N} 54^{\circ} 27^{\prime} 28^{\prime \prime} \mathrm{E}$, steppe, 17.VIII.2001, ESL \& FGS; 2 ○ $\sigma^{7}$ (PSU-3727), same locality, chalk slope with Cytisus, Stipa-grass steppe, 14-15.VI.2003, TTK; 2 O $\sigma^{7}$ (PSU7613), Svetlyi Distr., 'Ashchisayskaya Steppe' division of Orenburg Reserve $\left(50^{\circ} 57^{\prime} 38^{\prime \prime} \mathrm{N}, 61^{\circ} 12^{\prime} 44^{\prime \prime} \mathrm{E}\right)$, white-land plots within Artemisia steppe, 25.VI.2017, ESL; 3 O $\sigma^{7}$ (PSU-7614), same locality, steppe with white-land plots, 25.VI.2017, ESL; 1 (PSU8263), Belyaevka Distr., 'Burtinskaya Steppe' division of Orenburg Reserve $\left(51^{\circ} 22^{\prime} \mathrm{N}, 5^{\circ} 59^{\prime} \mathrm{E}\right)$, steppe, VIII.2016, V.A. Nemkov. Chelyabinsk Area: 4 +0 (PSU-6534: as D. platnicki), Verkhneural'sk Distr., Leonovskie Gory Mt. Ridge, Bolshaya Mt., under stone, 27.VI.2009, TTK. Krasnoyarsk Territory: 1 (PSU-

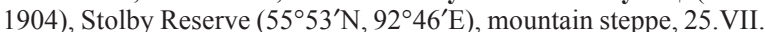
2001, A.Yu. Sipaeva. Tuva: 1 $\sigma^{7}$ (ISEA, det. Yu.M. Marusik), confluence of Biy-Khem (=Yenisei) and Uyuk Rivers $\left(52^{\circ} 04^{\prime} \mathrm{N}\right.$ 94²2'E), $670 \mathrm{~m}$ a.s.1., Stipa-Artemisia shrub steppe, 3-5.VI.1995, LDV. Chita Area: 1 (ISEA), Adon-Chelon massif, Tsalan-Obo Mt., c. 23 km E of Kholui-Baza, 8-9.VII.1996, V.V. Dubatolov, O.V. Kosterin; $1 O^{7}$ (ISEA), Daursky Nature Reserve, north bank of Zun-Torey Lake, steppe, 10-12.VI.1995, V.V. Dubatolov.
DESCRIPTION. The species is well-described and illustrated (the relevant references are given above).

REMARKS. The authors of the original description noticed that "the new species has unique for Drassodes long and curved into some loops seminal duct of the male bulbus" [Marusik, Logunov, 1995: 185]. Further studies have shown that this character is variable. The loop of the seminal duct does not always have a secondary curvature as in figs 26 and 28 in Marusik \& Logunov [1995] and often it is evenly rounded (see fig. 32.C in Song et al. [2004] or fig. 27 in Marusik \& Logunov [1995]). Such males are very difficult to distinguish from those of D. platnicki. According to our observations, the following diagnostic character is more stable and reliable: viz., the loop of the sperm duct is extended along the bulb (its apex is as if pushed-in) in $D$. longispinus (this loop is transverse in D. platnicki) and it is narrow in most of the specimens studied by us. Besides, all the Cis-Ural males, like those of the type series of $D$. longispinus, have an unclear but discernible dorsum colour pattern, similar to that of D. serratidens Schenkel, 1963. The male dorsum coloration of $D$. platnicki varies but always with no colour pattern of transverse stripes in the posterior half of dorsum.

Apparently, the males which were identified and illustrated as $D$. serratidens by $\mathrm{Hu} \& \mathrm{Wu}$ [1989] from the Chinese Province of Xinjiang show a dorsum colour pattern. However, by the shape of the seminal duct loop [ $\mathrm{Hu}, \mathrm{Wu}$, 1989: fig. 211.3], the illustrated male undoubtedly belongs to $D$. longispinus. The female illustrated by the same authors [Hu, Wu, 1989: fig. 211.1-2] is likely to belong to $D$. platnicki. Thus, we suspect that the records of D. serratidens from Xinjiang by $\mathrm{Hu} \& \mathrm{Wu}$ [1989: fig. 213, Map] should be referred to D. longispinus ( $\left.\sigma^{\top} \sigma^{7}\right)$ and ?D. platnicki $(+\circ)$.

The females of $D$. longispinus is similar to that of $D$. platnicki and D. jiufeng Tang, Song et Zhang, 2001, but can be separated from both by the short lateral epigynal margins, not reaching the terminal lobes of spermathecae ( $L M$, Figs $14,15)$. Besides, the basal lobes of spermathecae $(B L$, Figs $14,15)$ extend beyond the lateral margins of the fovea in $D$. longispinus (see also Seo [2017: fig.2.B-E]), whereas they are situated at the fovea margins in D. platnicki (Figs 17-18, aslo fig. 17 in Marusik \& Logunov [1995] and fig. 35.A-B in Song et al. [2004]).

Some of the Ural females of D. longispinus were misidentified by Esyunin \& Tuneva, [2002] and Tuneva \& Esyunin [2012] as D. platnicki.

DISTRIBUTION. Central-East-Palaearctic steppe-mountain range: from the South Urals to Korea.

Russia, the South Urals [Tuneva, Esyunin, 2012: as D. platnicki]; steppe of the Cis-Urals [Esyunin, Tuneva, 2002: as D. lesserti]; the steppe zone of West Siberia [present data]; South Siberia: the Altai, Krasnoyarsk and Zabaikalskiy areas and Tuva [Marusik, Logunov, 1995; Logunov et al., 1998; Danilov, 2008; Marusik et al., 2000; Azarkina, Trilikauskas, 2013; present data]; Mongolia: Töv Province [Marusik, Logunov, 2006]; China: Xinjiang, Tibet, Henan, Guangxi and Hebei provinces [Hu, Wu, 1989: sub D. serratidens; Song et al., 2004; Zhu, Zhang, 2011]; Korea [Seo, 2017].

Drassodes lutescens (C.L. Koch, 1839)

Fig. 16. $\left(O^{7}\right)$.

Drassodes mazurae Esyunin, Tuneva, 2002: 172, figs 15-18 


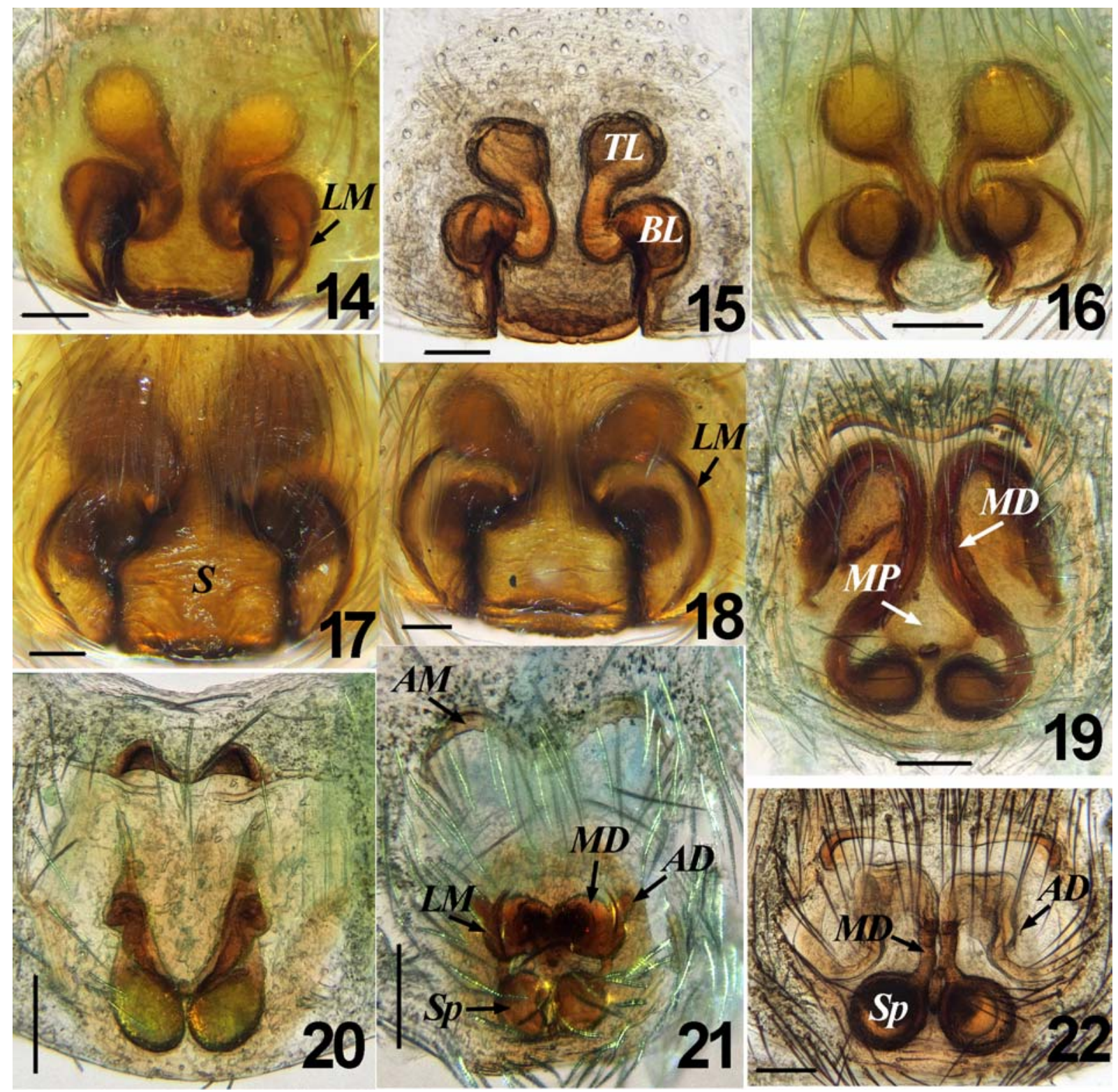

Figs 14-22. Epigyne of Drassodes longispinus Marusik et Logunov, 1995 (14-15), D. lutescens (C.L. Koch, 1839) (16), D. platnicki Song, Zhu et Zhang, 2004 (17-18), Drassyllus sur Tuneva et Esyunin, 2003 (19), Zelotes rufi Efimik, 1997 (20), Urozelotes trifidus Tuneva, 2003 (21) and Trachyzelotes manytchensis Ponomarev et Tsvetkov, 2006 (22). Abbreviations: $A D$ - anterior epigynal duct; $A M$ anterior epigynal margin; $B L$ - basal lobe of spermatecae; $L M$ - lateral epigynal margin; $M D$ - median epigynal duct; $S$ - septum; $S p$ - spermatecae; $T L$ - terminal lobe of spermatecae. Scale bars: $0.1 \mathrm{~mm}$.

Рис. 14-22. Эпигина Drassodes longispinus Marusik et Logunov, 1995 (14-15), D. lutescens (C.L. Koch, 1839) (16), D. platnicki Song, Zhu et Zhang, 2004 (17-18), Drassyllus sur Tuneva et Esyunin, 2003 (19), Zelotes rufi Efimik, 1997 (20), Urozelotes trifidus Tuneva, 2003 (21) и Trachyzelotes manytchensis Ponomarev et Tsvetkov, 2006 (22). Сокращения: $A D$ — передние каналы эндогины; $A M$ - передний край эпигины; $B L-$ базальная доля сперматеки; $L M-$ латеральный край эпигины; $M D-$ срединные каналы эндогины; $S$ - септум; $S p$ - сперматека; $T L$ - терминальная доля сперматеки. Масштаб: 0,1 мм.

Drassodes natali Esyunin, Tuneva, 2002: 173, figs 19-21 (+ only; mismatched).

Drassodes lutescens: Levy, 2004: 14, figs 33-39 (О’+9).

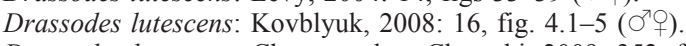

Drassodes lutescens: Chatzopoulou, Chatzaki, 2009: 352, figs 3-24 ( (O'P). [2018].

For a complete list of the taxonomic references see WSC

MATERIAL. Russia, Orenburg Area: 4 오 (PSU-1416: Paratypes D. natali), Kuvandyk Distr., 'Aituarskaya Steppe' divi- sion of Orenburg Reserve $\left(51^{\circ} 06^{\prime} 47^{\prime \prime} \mathrm{N}, 57^{\circ} 39^{\prime} 25^{\prime \prime} \mathrm{E}\right)$, southern rock slope, under stones, 15.V.1997, ESL; $1 \mathrm{O}^{7}$ (PSU-3710), 7 우 (PSU-3714), same distr., Kiy River $\left(50^{\circ} 58^{\prime} \mathrm{N}, 57^{\circ} 18^{\prime} \mathrm{E}\right)$, stony slope, under stones, 10-11.V.2003, TTK; 1 \& (PSU-3032), same distr., Karagala (= Katrala) River $\left(51^{\circ} 42^{\prime}\right.$ N, $\left.57^{\circ} 29^{\prime \prime} \mathrm{E}\right)$, stony slope, under stones, 2.VII.2002, TTK; 1 ○, 2 우 (PSU-7907), same distr., Shaytan-Tau Nature Reserve $\left(51^{\circ} 40^{\prime} \mathrm{N}, 57^{\circ} 27^{\prime} \mathrm{E}\right)$, stony steppe, under stones, 10.V.2018, ESL \& FGS; $20^{7} 0^{7}$ (PSU-3709), 6 우우 (PSU-3713), Sol-Iletsk Distr., c. $10 \mathrm{~km} \mathrm{~W}$ of Troitsk Vil., Chybynda (=Shybynda) gully $\left(50^{\circ} 40^{\prime} 52^{\prime \prime} \mathrm{N}, 54^{\circ} 27^{\prime} 28^{\prime \prime} \mathrm{E}\right)$, steppe on chalky 
rock, steppe, 7-10.VI.2003, TTK; 1 (P (PSU-7976), Belyaev Distr., nr. Donskoye Vil., Verblyuzhka Mt., steppe slope, 10.V.2009, TTK.

REMARKS. The type series of D. natali Esyunin, Tuneva, 2002 turned out to be heterogeneous. The holotype male is conspecific with D. platnicki Song, Zhu et Zhang, 2004, the paratype males to $D$. longispinus, and the paratype females to D. lutescens (Fig. 16). For detail see Remarks given below under D. platnicki.

DISTRIBUTION. West-Central-Palaearctic subborealsteppe range [Kovblyuk, Kastrygina, 2015].

\section{Drassodes platnicki Song, Zhu et Zhang, 2004} Figs 8-10, 17, 18.

Drassodes lesserti Schenkel, 1936: 254, fig. 83 ( $0^{7}$; preoccupied by $D$. hispanus lesserti Schenkel, 1936). $\left(0^{\top}+\right)$.

Drassodes lesserti: Marusik, Logunov, 1995: 182, figs 13-18

Drassodes natali Esyunin, Tuneva, 2002: 173, figs 22-25 (holotype $\sigma^{7}$ only). Syn.n.

Drassodes platnicki: Song et al., 2004: 67, fig. 35A-D ( $\sigma^{\top}+$; replaced name). [2018]

For a complete list of the taxonomic references see WSC

MATERIAL. Russia, Orenburg Area: $3 \sigma^{7} \sigma^{7}$ (PSU-5908), Belyaev Distr., near Donskoye Vil., Verblyuzhka Mt., steppe slope, 10.V.2009, TTK. Tuva: $2 \sigma^{\top} \sigma^{\top}, 3$ 우 (ISEA), Ovyursky Distr., c. $10 \mathrm{~km} \mathrm{~N}$ of Ak-Chyraa Vil., Irbitel River valley $\left(50^{\circ} 44^{\prime \prime} \mathrm{N}, 93^{\circ} 08^{\prime \prime} \mathrm{E}\right)$, 1000-1050 m a.s.1., 13-16.VI.1995, LDV; 1 o', 5 우 (ISEA), south-eastern Tuva, Tes-Khem River valley $\left(50^{\circ} 19^{\prime} \mathrm{N}, 95^{\circ} 01^{\prime} \mathrm{E}\right)$, 10.VI.1995, Yu.M. Marusik; 2 우 (ISEA), south-eastern Tuva, north-eastern bank of Ubsunur Lake $\left(50^{\circ} 40^{\prime} \mathrm{N}, 92^{\circ} 58^{\prime} \mathrm{E}\right)$, c. $750 \mathrm{~m}$ a.s.1., Leymus-Salvia-Caragana association, 18.VII.1993, LDV; 10 $\sigma^{7} \sigma^{7}, 3$ 우 (ISEA), same locality and habitat, 14.VI.1995, LDV; 1 $\sigma^{7}$ (ISEA), c. $5 \mathrm{~km}$ E of Kyzyl, Yenisei River valley, c. $700 \mathrm{~m}$ a.s.1., Salvia association, 15-22.V.1990, LDV; $2 \sigma^{7} \sigma^{\top}, 1$ ( 1 (ISEA), 3-5 $\mathrm{km}$ N of Kyzyl, 700-800 m a.s.1., Nanophyton steppe, 1.V.1990,

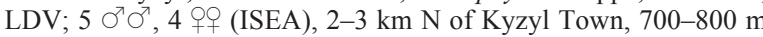
a.s.1., Nanophyton steppe, 20.V.1989, LDV; 1 (ISEA), nr. Kyzyl, c. $700 \mathrm{~m}$ a.s.1., Stipa-Artemisia steppe, 25.VI.1989, LDV; 9 OO (ISEA), c. $5 \mathrm{~km}$ E of Kyzyl, 700-900 m a.s.1., Stipa-Artemisia steppe, 3.VII.1989, LDV; 1 (ISEA), c. $3 \mathrm{~km} \mathrm{~S}$ of Kyzyl, c. $700 \mathrm{~m}$ a.s.1., Stipa-Artemisia steppe, 20.VII.1989, LDV; 1 + (ISEA), Mongun-Tayga Distr., Kargy River valley, 1700-1800 m a.s.1., SalexPopulus-Larix forest, 20.V.1990, LDV; $1 \sigma^{7}, 3$ 우 (ISEA), Mongun-Tayga Distr., 4-7 km SE Mugun-Aksy Vil., Kargy River valley, 5.VI.1990, LDV; 1 (ISEA), Piy-Khemsky Distr., c. 5 km NE of Seserlig Vil., 1000-1100 m a.s.1., steppe slope, 24.V.1989, LDV; $2 \sigma^{7} \sigma^{7}$ (ISEA), Piy-Khemsky Distr., c. $10 \mathrm{~km}$ SE of Seserlig Vil., 1100-1200 m a.s.1., Stipe-Artemisia steppe, 2.V.1990, LDV $1 \bigcirc^{7}, 6$ + Yamaalych Mt. Range, 1200-1300 m a.s.1., 9-10.VI.1989, LDV; 1 o (ISEA), c. $20 \mathrm{~km} \mathrm{NW}$ of Erzin Vil., c. $800 \mathrm{~m}$ a.s.1., 31.V.1989, LDV; $2 \sigma^{\top} \sigma^{\top}$ (ISEA), c. $2 \mathrm{~km}$ W of Erzin Vil., Erzin River valley, c. $1000 \mathrm{~m}$ a.s.1., 23.VI.1990, LDV \& O.V. Lyakhov; 2 우 (ISEA), 20-25 km W of Erzin Vil., Onchalaan Mt. Range, 1300-1400 m a.s.1., under stones, 11-12.VIII.1989, LDV; 3 ठ $\sigma^{7}$ (ISEA), c. 20 $\mathrm{km} \mathrm{W}$ of Erzin Vil., Onchalaan Mt. Range, 1200-1300 m a.s.1., 27.V-1.VI.1989, LDV; $1 \sigma^{7}$ (ISEA), 3-5 km E of Erzin Vil., rock, 1100-1200 m a.s.1., 23-25.V.1990, LDV; 1 (ISEA), c. $20 \mathrm{~km} \mathrm{~W}$ of Erzin Vil., Tes-Khen River valley $\left(50^{\circ} 19^{\prime} \mathrm{N}, 95^{\circ} 01^{\prime} \mathrm{E}\right), 10 . \mathrm{VI}$. 1995, LDV.

REMARKS. Diagnostic characters of both males and females of $D$. platnicki from Tuva markedly vary. Coloration: carapace yellow with a brownish head to brown with a yellowish thoracic part; abdomen uniformly gray (dirty white in one specimen) or grey with a dark lanceolate spot to black with yellowish (or grey) specks forming a marble pattern (uniformly black in one specimen).
Male palp. Usually, the loop of the sperm duct is transverse, uniformly rounded symmetrical ('drop'-shaped), but it can be narrowed with more or less parallel sides ('halfellipse'- and 'finger'-shaped), not symmetrical with the projecting leading edge. RTA typically serrated, with numerous small teeth (Fig. 9), but it may possess two/three (even one) large denticles at the base only, or a large denticle at the base and numerous small teeth, or with a crenulate plate at the base and a smooth top (Fig. 10), etc.

Epigyne. The terminal lobe of the spermatheca is usually larger than the basal one (Fig. 17), rarely they are almost of the same size (Fig. 18). The lateral margins of the fovea extend forward to the posterior half of the terminal lobe (Fig. 18), rarely to their anterior half, sometimes to the posterior margin only (Fig. 17). The septum pentagonal, typically with parallel lateral rims (Figs 17, 18), but it may be with the rims tapering posteriorly. The width and length of the septum are typically equivalent, but the septum can also be longitudinal or transverse.

D. natali was described from two localities of the southern Cis-Ural steppe zone. Since then, this species has never been found from outside of the type locality. Re-examination of additional materials from Tuva and the types convinced us that the type series of $D$. natali was of a mixed nature. The holotype male of $D$. natali is conspecific with $D$. platnicki, while the paratype males are identical to $D$. longispinus and the paratype females to D. lutescens.

DISTRIBUTION. Central Ancient Mediterranean steppe range: from the western shore of Caspian Sea to northeastern China.

South European Russia: Dagestan, Rostov Area [Ponomarev et al., 2011; Abdurakhmanov et al., 2012; Ponomarev, Abdurakhmanov, 2014] (materials re-examined by A.V. Ponomarev); the steppe Cis-Urals: Orenburg Area [present data]; South Siberia: the Altai, Tuva, Buryatia [Danilov, 2008; Marusik, Logunov, 1995: sub D. lesserti, 2009]; Mongolia [Loksa, 1965: sub D. lesserti], north-eastern China [Song et al., 2004].

\section{Drassyllus sur Tuneva et Esyunin, 2003} Figs 11-13, 19.

Drassyllus sur Tuneva, Esyunin, 2003a: 223, figs 1-4 ( $\sigma^{7}$ ) Drassyllus sur: Kovblyuk et al., 2009: 177, figs 27-28 ( ( $\left.{ }^{7}\right)$. Drassyllus sur: Chatzaki, Russell-Smith, 2017: 244, figs 17, 21-22, 24 ( ( + + ).

MATERIAL. Russia, Orenburg Area: $1+$ (PSU-3755), SolIletsk Distr., Novoiletsk Vil., 5-15.VI.2003, TTK; 4 ○フ $\sigma^{\top}, 7$ 우 (PSU-7572), Svetlyi Distr., 'Ashchisayskaya Steppe' division of Orenburg Reserve $\left(50^{\circ} 57^{\prime} 38^{\prime \prime} \mathrm{N}, 61^{\circ} 12^{\prime} 44^{\prime \prime} \mathrm{E}\right)$, various steppes, saline lake shore, VI.2015, SSS; 2 ○ $\sigma^{7}, 3$ Oᄋ (PSU-7573), same locality, sand drift, stony stepps, saline land, 15-27.VI.2016, ESL; $2 \bigcirc^{7}, 1$ (MMUE), same locality, multiherbaceous steppe with Glycyrrhiza, 16.VI.2016, ESL. Kazakhstan, South Kazakhstan Area: $8 \sigma^{\top} \sigma^{7}$ (PSU-6112), c. $7 \mathrm{~km} \mathrm{NE}$ of Terekty Vil., BoraldayTau Range $\left(42^{\circ} 51.751^{\prime} \mathrm{N}, 69^{\circ} 50.887^{\prime} \mathrm{E}\right), 11-13$.V.2010, TTK.

REMARKS. In the original diagnosis, Tuneva \& Esyunin [2003a] assumed that D. sur is superficially similar to two North American species: D. fallens Chamberlin, 1922 and D. saphes Chamberlin, 1936. That assumption is to be corrected, as D. sur is extremely close to D. cyprius Chatzaki et Russell-Smith, 2017, but the "embolus of D. cyprius almost straight, projection of embolar radix and terminal apophysis more pointed, median apophysis large and prominent at the ventral side of tegulum, shape of embolar haematodocha different" [Chatzaki, Russell-Smith, 2017: 244] 
and the epigyne with "wider anterior margin, longer anterior ducts, wider median ducts" [Chatzaki, Russell-Smith, 2017: 244]

Besides, D. sur is similar to several Palaearctic species, such as D. crimeaensis Kovblyuk, 2003 (Macedonia, Greece, southern Ukraine, Turkey, the south of European Russia, Azerbaijan [WSC, 2017]), D. jubatopalpis Levy, 1998 (Turkey, Israel [Kovblyuk et al., 2009]) and D. villicoides (Giltay, 1932) (Greece [Bosmans, 2013]). The male of D. sur differs from the last two species in having the straight RTA (Fig. 12) (bent dorsally in both D. jubatopalpis [Kovblyuk et al., 2009: fig. 26] and D. villicoides [Senglet, 2012: fig. $15])$ and from the first species in having the well-marked embolar projection $(e P$, Figs 11,13$)$ which invisible in $D$. crimeaensis [Kovblyuk, 2003: figs 1, 2, 13; Kovblyuk et al., 2009: fig. 23].

The females of three species, D. crimeaensis, D. jubatopalpis and $D$. sur, have a well-defined posterior margin of the epigynal middle piece (MP, Fig. 19), whereas it is not marked in D. villicoides [Senglet, 2012: fig. 17; Bosmans, 2013: fig. 3]. The female of D. jubatopalpis is characterized by the curved median epigynal ducts [Levy, 1998: fig. 137] (straight in D. crimeaensis and D. sur). The last two species can be distinguished by the shape of epigynal middle piece, which is cruciform in D. crimeaensis [Kovblyuk, 2003: fig. 3] and drop-shaped in D. sur (Fig. 19 and fig. 1 in Tuneva \& Esyunin [2003a]).

DISTRIBUTION. Central Ancient Mediterranean steppe range: from the western shore of Caspian Sea and Iran to Central Kazakhstan and the steppe Cis-Urals.

South European Russia: Rostov, Astrakhan, Volgograd and Orenburg Areas [Tuneva, Esyunin, 2003a; Ponomarev \& Tsvetkov, 2004; Ponomarev et al., 2008; Ponomarev, Khnykin, 2013]. Kazakhstan: Akmola, Kostanay, South Kazakhstan and Western Kazakhstan Areas [Piterkina, 2009; Gromov, 2011; Ponomarev, Bragina, 2014; present data] Turkey: Adana Province [Kovblyuk et al., 2009]. Iran: Khorasan-e-Razavi Province [Zamani et al., 2014].

\section{Gnaphosa lucifuga (Walckenaer, 1802) Figs 23-31.}

Gnaphosa lucifuga: Tullgren, 1946: 78, fig. 23A-B, Pl. 12, figs $154-156$ ( $\left.\sigma^{\top}+\right)$.

Gnaphosa lucifuga: Grimm, 1985: 60, figs 43, 60-61 ( $\left.\sigma^{\top}+\right)$. $\left(\sigma^{7}+\right)$.

Gnaphosa lucifuga: Ovtsharenko et al., 1992: 5, figs 1-6

Gnaphosa betpaki (nec Ovtsharenko et al.): Tuneva, Esyunin, 2003a: 230, fig. 26 ( $\sigma^{7}$, misidentification).

Gnaphosa lucifuga: Kovblyuk, 2005: 134, figs 1-5 ( $\sigma^{7}+$ ).

For a complete list of the taxonomic references see WSC [2018]

MATERIAL. Russia, Orenburg Area: $8 \sigma^{7} \sigma^{7}, 1$ (PSU1843), Sol-Iletsk Distr., c. $10 \mathrm{~km} \mathrm{~W}$ of Troitsk Vil., Chybynda (=Shybynda) gully $\left(50^{\circ} 40^{\prime} 52^{\prime \prime} \mathrm{N}, 54^{\circ} 27^{\prime} 28^{\prime \prime} \mathrm{E}\right)$, chalk declivity, dry riverbed, V.2000 \& VIII.2001, ESL \& FGS; 2 Oᄋ (PSU-1850), same locality, saline land, 14-23.VIII.2001, ESL \& FGS; 2 ○ (PSU-3743), same locality, dry riverbed and windbreak, 7-14.VI 2003, TTK; 1 क (PSU-4997), same locality, chalk slope, 9.VI.2000, ESL; 1 O (PSU-7271), same locality, steppe with Stipa, 513.VI.2000, ESL; 2 Oᄋ (PSU-2672), Svetliy Distr., feather grass (Stipa) and wormwood (Artemisia) steppes, VI and VII.2009, TTK $6 \bigcirc^{7} \sigma^{\prime}, 2$ 우 (PSU-4273), Orenburg Distr., 3 km NE Pervomajskij Vil., Donguzskaya Steppe $\left(51^{\circ} 33^{\prime} 14^{\prime \prime} \mathrm{N} 55^{\circ} 01^{\prime} 37^{\prime \prime} \mathrm{E}\right)$, feather grass (Stipa) steppe, 20.V-4.VI.2007, KVO; $1 \sigma^{7}, 1$ (ZMMU), same locality, feather grass (Stipa) steppe, 9.IV-3.V.2008, KVO; 1 \% (PSU-6558), Orenburg Distr., c. $3 \mathrm{~km} \mathrm{NE}$ of Nezhinka Vil. (51 $47^{\prime} 21^{\prime \prime} \mathrm{N}, 55^{\circ} 22^{\prime} 45^{\prime \prime} \mathrm{E}$ ), steppe, 25.V-11.VI.2008, KVO; $1 \sigma^{7}$ (PSU-
6566), Orenburg Distr., c. $15 \mathrm{~km}$ NE of Orenburg, Grebeni Mt. $\left(51^{\circ} 56^{\prime} 29^{\prime \prime} \mathrm{N}, 55^{\circ} 16^{\prime} 48^{\prime \prime} \mathrm{E}\right)$, steppe, 21.V-27.VI.2009, KVO; 3 O $^{\top} \sigma^{\top}$, 1 q (MMUE), same locality, steppe, 7.V-12.VI.2008, KVO; 2 $\sigma^{\top} \sigma^{\top}, 2$ 오 (MMUE), Svetlyi Distr., 'Ashchisayskaya Steppe' division of Orenburg Reserve $\left(50^{\circ} 57^{\prime} 38^{\prime \prime} \mathrm{N}, 61^{\circ} 12^{\prime} 44^{\prime \prime} \mathrm{E}\right)$, steppe, VI.2015, SSS; 3 ○ $\sigma^{7}$ (PSU-7574), same locality, steppe, 37.V.2015, ESL \& Dedyukhin S.V.; $7 \sigma^{7} \sigma^{7}, 4$ 90 (PSU-7575), same locality, various steppes, VI.2015, SSS; 5 O$^{7} \sigma^{7}, 1 \%$ (PSU-7576), same locality, saline land, 27.VI.2017, ESL; 1 ○ (PSU-8264), Belyaevka Distr., 'Burtinskaya Steppe' division of Orenburg Reserve $\left(51^{\circ} 22^{\prime} \mathrm{N}, 55^{\circ} 59^{\prime} \mathrm{E}\right)$, steppe, VIII.2016, V.A. Nemkov.

COMPARATIVE MATERIAL. Gnaphosa betpaki Ovtsharenko, Platnick et Song, 1992: 1 \& (PSU-5986), Kazakhstan, Chimkent (=South Kazakhstan) Area, c. $40 \mathrm{~km} \mathrm{E} \mathrm{of} \mathrm{Koksaray} \mathrm{Vil.,} \mathrm{desert}$ $\left(42^{\circ} 27.837^{\prime} \mathrm{N}, 67^{\circ} 41.292^{\prime} \mathrm{E}\right), 2$.V.2010, TTK.

REMARKS. This large and widespread species has been redescribed and illustrated many times. The specimens from Orenburg have minor differences in the conformation of the male palp and epigyne (Figs 25-31). Male palp (Fig. 23): the number of embolic tubercles varies considerably as well as their shapes (Figs 25-29). The male from Western Kazakhstan, of which a SEM photograph is shown by Ovtsharenko et al. [1992: fig. 5], have the right conical embolic tubercles. Epigyne (Figs 30, 31): the epigynal hood with large or small number of pleats, as well as with a triangular/ arcuate impression at the posterior margin. In Ovtsharenko's SEM photograph [Ovtsharenko et al., 1992: fig. 6], the epigynal hood looks more rectangular, with poorly expressed pleats and a posterior impression.

The records $G$. betpaki from Orenburg Area [Tuneva, Esyunin, 2003a] turned out to be a misidentification, and should actually be referred to G. lucifuga (the museum specimens, no. PSU-1843, PSU-1850, PSU-2672, have been reexamined). Therefore, we have excluded $G$. betpaki from the current list of Ural spiders. G. betpaki is distributed in South Kazakhstan, Zhambyl and Kzyl-Orda Areas of Kazakhstan only [Ovtsharenko et al., 1992].

DISTRIBUTION. West-Central-Palaearctic subboreal range: from Iberian Peninsula to Xinjiang, northward to South Sweden in Europe and to southern West Siberian in Asia, southward to the Mediterranean, Azerbaijan and Uzbekistan.

Gnaphosa pilosa Saveljeva, 1972 Figs 32-37.

Gnaphosa pilosa Savelyeva, 1972: 1240, figs 3-4 (). $\left(\bigcirc^{\top}+\right)$

Gnaphosa pilosa: Ovtsharenko et al., 1992: 24, figs 75-78

MATERIAL. Russia, Orenburg Area: $10 \sigma^{\top} \sigma^{7}, 2$ (PSU-

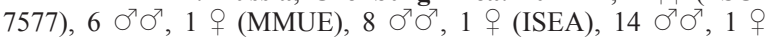
(ZMMU), Svetlyi Distr., 'Ashchisayskaya Steppe' division of Orenburg Reserve (505 $\left.57^{\prime} 38^{\prime \prime} \mathrm{N}, 61^{\circ} 12^{\prime} 44^{\prime \prime} \mathrm{E}\right)$, various steppes, VI.2015, SSS. Kazakhstan, East Kazakhstan Area: $1 \uparrow$ (PSU-3231), nr. Zaisan Lake, 2200 m a.s.1., under stone, VII.1936, D.E. Kharitonov.

REMARKS. The conformation of the male palps in the studied specimens slightly differs from the illustrations given by Ovtsharenko et al. [1992: fig. 75, 76], who noticed that the RTA of their specimens was bifid. Our males have a triangular protrusion near the RTA apex ( $p r$, Fig. 35). Other characters in both sexes correspond to the species description. Yet, the studied female from East Kazakhstan is identical to those from the Cis-Ural steppe.

$G$. pilosa is close to the following species of the lugubris group: viz., G. caucasica Ovtsharenko, Platnick et Song, 1992, G. lapponica (L. Koch, 1866) and G. pseashcho Ovtsharenko, Platnick et Song, 1992. The males of G. pilosa 


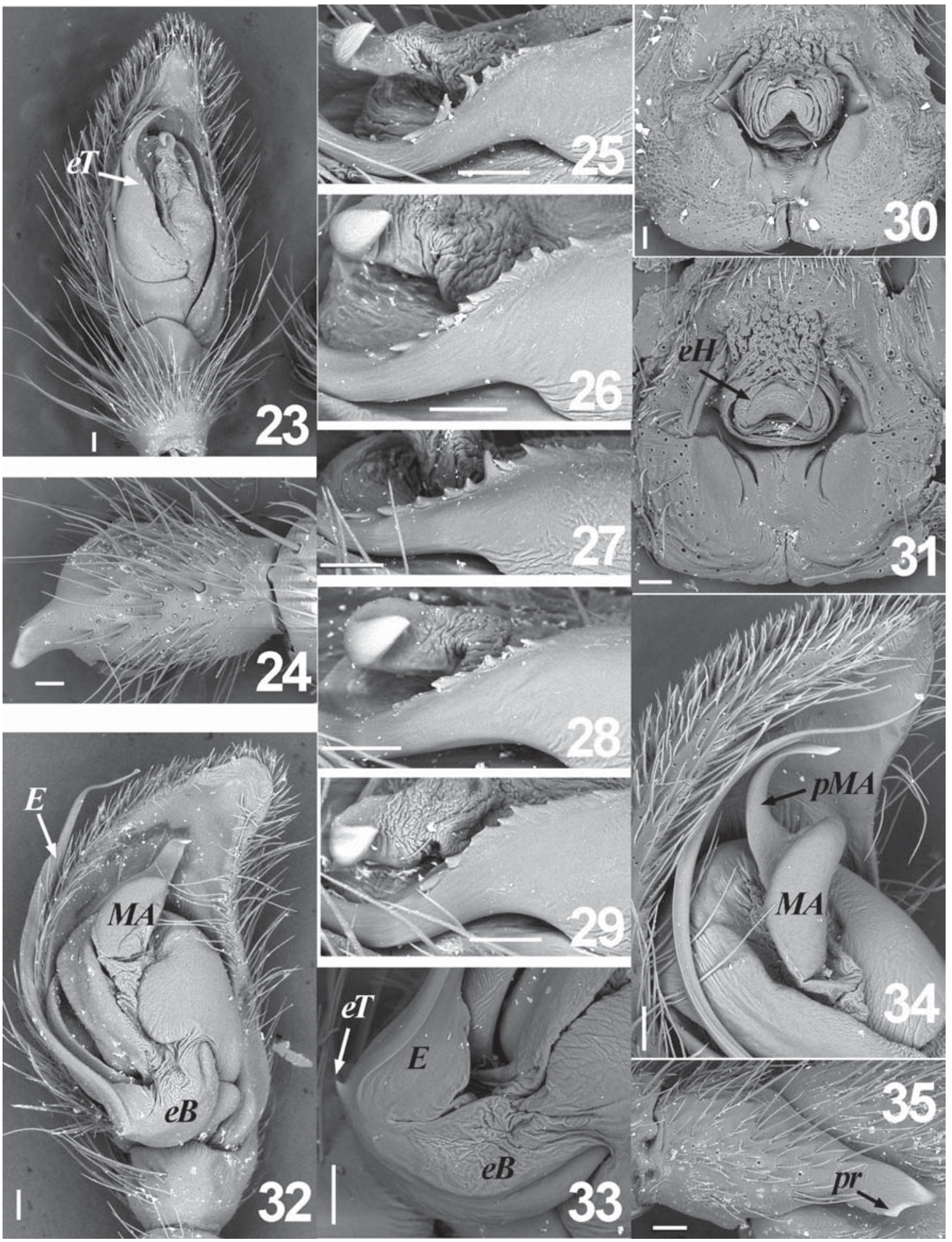

Figs 23-35. Gnaphosa lucifuga (Walckenaer, 1802) (23-31) and G. pilosa Saveljeva, 1972 (32-35), scanning electron micrographs: 23, 32 - male palp, ventral view, 24, 35 - tibia of male palp, lateral view, 25-29 - embolic tubercles, 30, 31 - epigyne, ventral view, 33 - embolic base and basal part of embolus, 34 - medial apophysis of male palp, lateral view. Abbreviations: $E-$ embolus; $e B-$ embolus base; $e H-$ epigynal hood; $e T-$ embolic tubercles; $M A-$ median apophysis; $p M A-$ process of MA; $p r-$ triangular protrusion of retrolateral tibial apophysis. Scale bars: $0.1 \mathrm{~mm}$.

Рис. 23-35. Gnaphosa lucifuga (Walckenaer, 1802) (23-31) и G. pilosa Saveljeva, 1972 (32-35), сканирующие электронные микрофотографии: 23,32 - пальпа, снизу; 24, 35 - голень пальпа самца, сбоку; 25-29 - зубчики эмболюса; 30,31 - эпигина, снизу; 33 - база эмболюса и его основание, 34 - срединный отросток пальпа самца, сбоку. Сокращения: $E$ - эмболюс; $e B-$ основание эмболюса; $e H$ - «колпачок» эпигины; $e T$ — зубчики эмболюса; $M A$ - срединный отросток; $p M A$ — вырост MA; $p r-$ треугольный выступ ретролатерального отростка голени. Масштаб: 0,1 мм. 

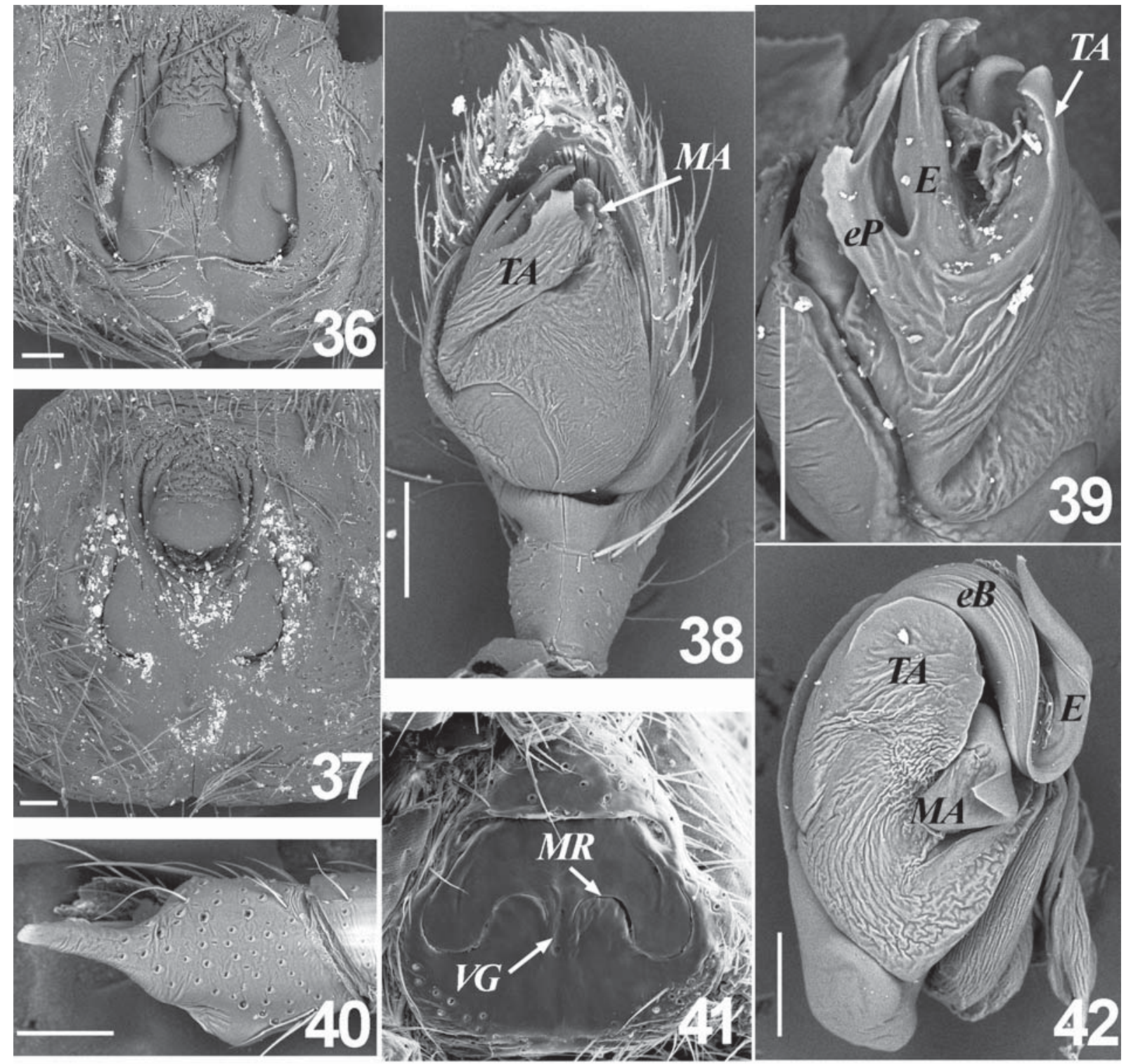

Figs 36-42. Gnaphosa pilosa Savelyeva, 1972 (36-37), Urozelotes trifidus Tuneva, 2003 (38-40) and Trachyzelotes manytchensis Ponomarev et Tsvetkov, 2006 (41-42), scanning electron micrographs: 36, 37, 41 - epigyne, ventral view; 38 - male palp, ventral view; 39 - embolic division; 40 - tibia of male palp, lateral view; 42 - bulbus, ventral view. Abbreviations: $E$ - embolus; $e B$ - embolic base; $e P$ - embolic projection; $M A$ - median apophysis; $M R$ - median ridge of epigyne; $T A$ - terminal apophysis, $V G-\mathrm{V}$-shaped groove of epigyne. Scale bars: $0.1 \mathrm{~mm}$.

Рис. 36-42. Gnaphosa pilosa Saveljeva, 1972 (36-37), Urozelotes trifidus Tuneva, 2003 (38-40) and Trachyzelotes manytchensis Ponomarev et Tsvetkov, 2006 (41-42), сканирующие электронные микрофотографии: 36, 37, 41 - эпигина, снизу; 38 - пальпа самца, снизу; 39 - эмболюсный отдел; 40 - голень пальпа самца, сбоку; 42 - бульбус, снизу. Сокращения: $E$ - эмболюс; $e B-$ основание эмболюса; $e P$ - отросток эмболюса; $M A$ - срединный отросток; $M R$ - срединный гребень эпигины; $T A$ - терминальный отросток, $V G-\mathrm{V}$-образная борозда эпигины. Масштаб: 0,1 мм.

can be distinguished by the curved median apophysis pointed at its tip (MA; Fig. 34) and the curved embolus with a single embolic tubercule basally ( $e T$; Fig. 33 ). The females can be separated by an oblong midpiece of the epigyne with straight posterior margin (Figs 36, 37).

DISTRIBUTION. Central-Asian steppe range: species is known from Karaganda and East Kazakhstan Areas of Kazakhstan [Savelyeva, 1972; Ovtsharenko et al., 1992; Tuneva, 2004] and from the border of Aktyubinsk and Orenburg Areas [present data], as well as from the Altai [Azarkina, Trilikauskas, 2013].

\section{Trachyzelotes manytchensis \\ Ponomarev et Tsvetkov, 2006}

Figs 22, 41-46.

Trachyzelotes sp.: Ponomarev, Tsvetkov, 2004: 95, fig. 2.1314 ( (O'P).

Trachyzelotes manytchensis Ponomarev, Tsvetkov, 2006: 11, figs $18-19\left(0^{7}\right.$ ? $)$.

Trachyzelotes manytchensis: Ponomarev et al., 2016: 10, figs 5-8 (O'P).

MATERIAL. Russia, Orenburg Area: $30^{7} \sigma^{7}, 4$ ㅇ (PSU7977), Svetlyi Distr., 'Ashchisayskaya Steppe' division of Oren- 

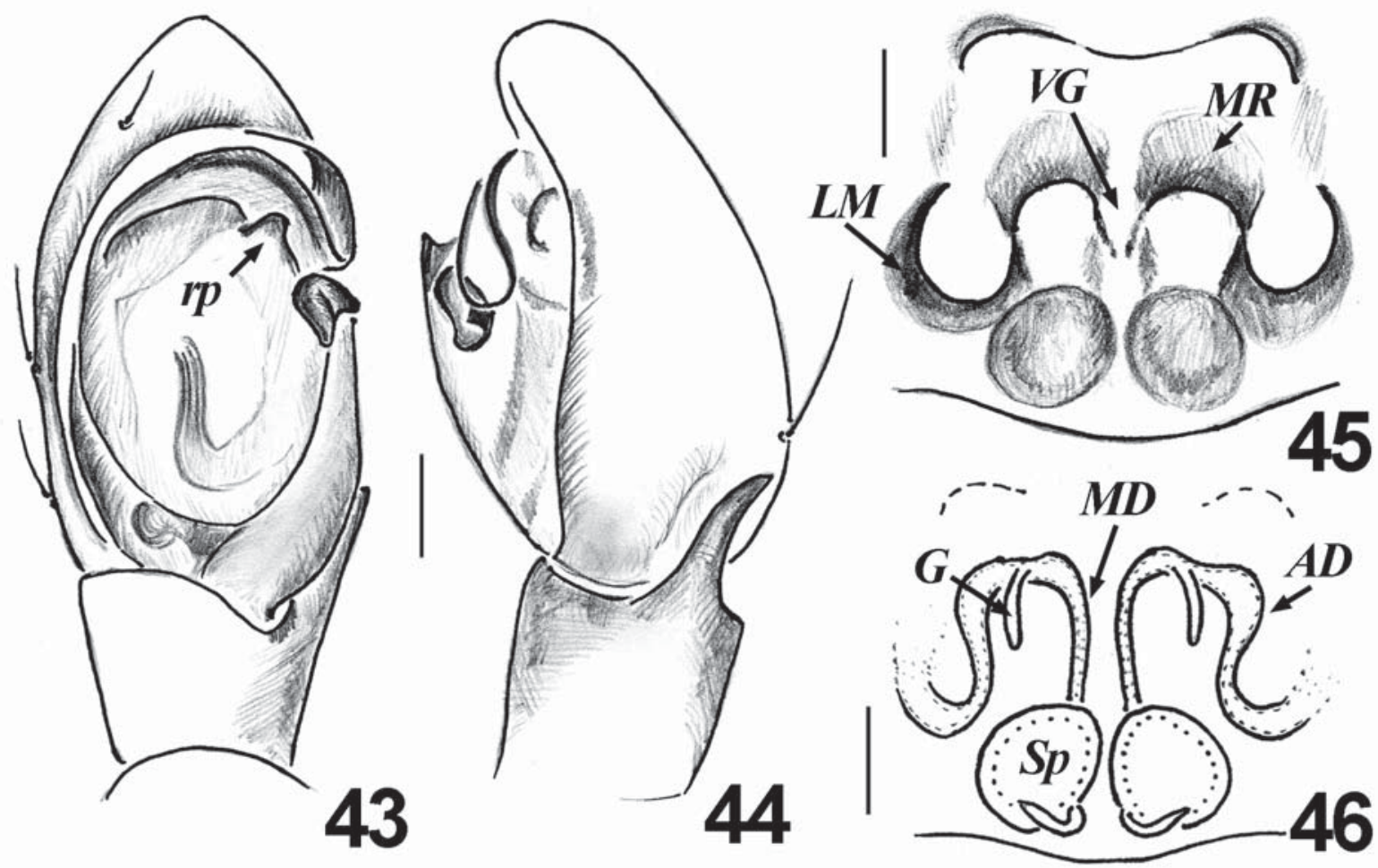

Figs 43-46. Trachyzelotes manytchensis Ponomarev et Tsvetkov, 2006: 43, 44 - male palp, ventral and lateral view; 45, 46 epigyne, ventral and dorsal view. Abbreviations: $A D$ - anterior epigynal duct; $G$ - spermathecal gland; $L M$ - lateral epigynal margin; $M D$ - median epigynal duct; $M R$ - median ridge of epigyne; $r p$ - retrolateral process of terminal apophysis, $S p$ - spermathecae; $V G$ V-shaped groove of epigyne. Scale bars: $0.1 \mathrm{~mm}$.

Рис. 43-46. Trachyzelotes manytchensis Ponomarev et Tsvetkov, 2006: 43, 44 — пальпа, снизу и сбоку; 45, 46 — эпигина, снизу и сбоку. Сокращения: $A D$ - передние каналы эндогины; $G$ - железа сперматеки; $L M$ - боковой край эпигины; $M D$ - срединный канал эндогины; $M R$ - срединный гребень эпигины; $r p$ - ретролатеральный вырост терминального отростка, $S p$ - сперматека; $V G$ - V-образная борозда эпигины. Масштаб: 0,1 мм.

burg Reserve $\left(50^{\circ} 57^{\prime} 38^{\prime \prime} \mathrm{N}, 61^{\circ} 12^{\prime} 44^{\prime \prime} \mathrm{E}\right)$, various steppes, 4.VI5.VII.2015, SSS; 1 ㅇ (PSU-8267), Belyaevka Distr., 'Burtinskaya Steppe' division of Orenburg Reserve $\left(51^{\circ} 22^{\prime} \mathrm{N}, 55^{\circ} 59^{\prime} \mathrm{E}\right)$, steppe, VIII.2016, V.A. Nemkov.

REMARKS. T. manytchensis was originally described from Rostov Area of Russia [Ponomarev, Tsvetkov, 2006]. Based on the examination of the male and two females of $T$. manytchensis from Kohgiluyeh and Boyer-Ahmad Provinces of Iran, Senglet [2011: 530] concluded that their "genitalia show a close relationship with the Zelotes tenuis species group" and established a new combination - Zelotes manytchensis [Senglet, 2011: 527]. Recently, Ponomarev et al., [2016] restored the original combination and also suspected that "perhaps Senglet dealt with another species close to $T$. manytchensis" [Ponomarev et al., 2016: 11]. We had an opportunity to examine a female from Iran. Its epigyne is consistent with the pictures presented by Senglet [2011: figs $63,64,77]$ for the Iranian females. Thus, we are convinced that the Iranian species reported by Senglet [2011] under the name of Zelotes manytchensis is a separate, undescribed Zelotes species.

True T. manytchensis belongs to the barbatus species group [sensu Platnick \& Murphy, 1984] reasoning from the following group's diagnostic characters: the distally rounded terminal apophysis $(T A)$ and embolar base (eB; Fig. 42), and the anterior-laterally expanded anterior epigynal ducts $(A D$; Fig. 46).
By the position and shape of the retrolateral process of the terminal apophysis ( $r p$, Fig. 43), the males of T. manytchensis are most similar to those of T. bardiae (Caporiacco, 1928) (Portugal, Spain, Algeria, Libya [Levy, 1998]) and $T$. glossus (Strand, 1915) (Israel, Turkey [WSC, 2017]). T. manytchensis can be distinguished from T. glossus by the longer RTA which is approximately equal to the length of the palpal tibia [Ponomarev et al., 2016: fig. 8] (RTA is shorter, equal to about a half of the length of the palpal tibia in T. glossus [Levy, 1998: fig. 30]). T. manytchensis can be separated from $T$. bardiae by the shorter loop of embolus (in lateral view) that does not reach the middle part of the cymbium (Fig. 44) (the loop of embolus reaches the middle part of the cymbium in T. bardiae [Platnick, Murphy, 1984: fig. 44]).

By the conformation of the epigyne, the females of $T$. manytchensis are most similar to those of T. bardie [sensu Levy, 1998] known from Spain, Morocco, Algeria, Israel, $T$. mutabilis (Simon, 1878) (Mediterranean [WSC, 2017]) and T. ravidus (L. Koch, 1875) (Ethiopia [Platnick, Murphy, 1984]). T. manytchensis differs from the related species in having the S-shaped anterior epigynal ducts of endogyne (AD, Fig. 22, 46) (anterior epigynal ducts arcuately rounded in T. bardie [Levy, 1998: fig. 32], T. mutabilis and T. ravidus [Platnick, Murphy, 1984: figs 18, 42]). 
It is worth noticing a similarity between the females of T. manytchensis and T. ansimensis Seo, 2002 (the male is unknown [Seo, 2002]) described from South Korea. Both species are characterized by the median epigynal margin extending backward and forming a narrow $\mathrm{V}$-shaped groove ( $V G$, Figs 41, 45), the S-shaped anterior epigynal ducts of endogyne, and identical somatic morphology. It is likely that both species names are synonymous, as, for instance, was recently established for Ermetus inopinabilis Ponomarev, 2008 and E. koreana (Paik, 1967) [Lissner, 2018].

DISTRIBUTION. The steppe zone of Russia, from Rostov Area [Ponomarev, Tsvetkov, 2004, 2006; Ponomarev et al., 2016] to Orenburg Area [present data].

\section{Urozelotes trifidus Tuneva, 2003 Figs 21, 38-40.}

Urozelotes trifidus Tuneva, 2003: 95, figs 1-6 (o'우).

Urozelotes trifidus: Milano et al., 2019: 37, fig. 5 ( $\left.\sigma^{7}+\right)$.

MATERIAL. Russia, Orenburg Area: $11 \sigma^{7} \sigma^{7}, 4$ oO (PSU7604), Svetlyi Distr., 'Ashchisayskaya Steppe' division of Orenburg Reserve $\left(50^{\circ} 57^{\prime} 38^{\prime \prime} \mathrm{N}, 61^{\circ} 12^{\prime} 44^{\prime \prime} \mathrm{E}\right)$, saline land, shore of a

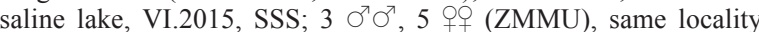
and habitat, 7.V.2015, ESL; 10 ○ $\sigma^{\top}, 5$ O+ (MMUE), same locality, sand drift, saline sandy shore of a steppe lake, bed of ephemeral impounded body, VI.2016, ESL; 3 O $^{7}, 5$ 우 (ISEA), same locality and habitat, 26.VI.2017, ESL.

REMARKS. All four species of the genus Urozelotes Mello-Leitão, 1938 have peculiar properties in the structure of the embolar division, except for $U$ patulus Sankaran et Sebastian, 2018 from Western Ghats of India which seems not to belong to this genus. U. trifidus is characterized by the embolar projection bifurcated at its apex ( $e P$; Fig. 39) and the tabulate terminal apophysis with a serrated anterior margin (TA; Fig. 38). By the shape of the epigynal fovea and the structure of the endogyne, the females of $U$. trifidus are very similar to those of $U$. kabenge FitzPatrick, 2005 from Zambia, but can be distinguished by the presence of a median ridge on the epigynal plate, which is absent from the latter species [FitzPatrick, 2005: fig. 10].

DISTRIBUTION. To date, the species is known from three distant regions only: south-eastern France (riparian habitats, $1146 \mathrm{~m}$ a.s.1. [Milano et al., 2019]), the Cis-Ural steppe zone (riparian habitats) [present data] and Novosibirsk Area in West Siberia [Azarkina et al., 2018].

\section{"Zelotes" rufi Efimik, 1997}

Figs 20, 47-49.

(+).

Zelotes rufi Efimik in Esyunin, Efimik, 1997: 107, figs 17-18

"Zelotes" fallax Tuneva et Esyunin, 2003a: 225, figs 10-14 (O) Syn.n.

MATERIAL. Russia, Orenburg Area: 1 \% (PSU-1935: paratype of Z. fallax), Sol-Iletsk Distr., c. $10 \mathrm{~km} \mathrm{~W}$ of Troitsk Vil., Chybynda (=Shybynda) gully $\left(50^{\circ} 40^{\prime \prime} 52^{\prime \prime} \mathrm{N}, 54^{\circ} 27^{\prime \prime} 28^{\prime \prime} \mathrm{E}\right)$, chalk slope, 5-12.VI.2000, ESL \& FGS; $40^{7} \sigma^{7}, 1$ \% (PSU-7608), Svetlyi Distr., 'Ashchisayskaya Steppe' division of Orenburg Reserve $\left(50^{\circ} 57^{\prime} 38^{\prime \prime} \mathrm{N}, 61^{\circ} 12^{\prime} 44^{\prime \prime} \mathrm{E}\right)$, rubbly steppe, $15-16 . \mathrm{VI} .2016,25$.VI 2017, ESL; $2 \sigma^{7} \sigma^{7}$ (MMUE), same locality, Artemisia steppe, 16. VI.2016, ESL; $2 O^{7} \sigma^{7}$ (PSU-7609), same locality, Artemisia steppe on white land, 25-26.VI.2017, ESL; 1 (PSU-7610), same locality, worm-wood (Artemisia) steppe, 27.VI.2017, ESL. Kazakhstan, Karaganda Area: $2 \mathrm{O}^{7} \mathrm{O}^{7}$ (ISEA), c. $6 \mathrm{~km} \mathrm{~S}$ of Barshin (=Barshino) Vil., saline land along Saryzhol Lake $\left(49^{\circ} 37^{\prime} \mathrm{N}, 69^{\circ} 28^{\prime} \mathrm{E}\right)$, pitfall-traps, 2-7.VI.2018, I.I. Lyubechanskii \& G.N. Azarkina.

REMARKS. Z. rufi was described from the holotype female collected from steppe meadows in Meleuz District of
Bashkortostan [Esyunin, Efimik, 1997]. Later, Z. fallax was described from two males collected from chalk cliffs in SolIletsk District of Orenburg Area [Tuneva, Esyunin, 2003a].

The material collected from "Ashchisayskaya steppe" contains the males of $Z$. fallax and a single female of $Z$. rufi. No other (unknown) Zelotes species have been found in this locality for three years of the research. Moreover, the specimens of Z. fallax and Z. rufi do not differ in somatic characters, and in two samples both sexes were collected from the same biotope. Thus, we have come to the conclusion that $Z$. fallax is to be considered a junior synonym of $Z$. rufi. The systematic position of $Z$. rufi, viz. its correct generic assignment, remains unclear.

DISTRIBUTION. The steppe regions of South Urals and Cis-Urals: Bashkortostan Republic [Esyunin, Efimik, 1996], Orenburg Area [Tuneva, Esyunin, 2003a] and Central Kazakhstan [present data].

\section{New faunistic records}

\section{Gnaphosa mandschurica Schenkel, 1963}

MATERIAL. Russia, Orenburg Area: $1 \sigma^{7}$ (PSU-7978), Svetlyi Distr., 'Ashchisayskaya Steppe' division of Orenburg Reserve $\left(50^{\circ} 57^{\prime} 38^{\prime \prime} \mathrm{N}, 61^{\circ} 12^{\prime} 44^{\prime \prime} \mathrm{E}\right)$, shore of a saline lake, 14-25.VI.2015, SSS; 1 क (PSU-8266), Belyaevka Distr., 'Burtinskaya Steppe' division of Orenburg Reserve $\left(51^{\circ} 22^{\prime} \mathrm{N}, 55^{\circ} 59^{\prime} \mathrm{E}\right)$, steppe, VIII.2016, V.A. Nemkov.

DISTRIBUTION. Central Asian steppe range, with isolated populations down the Siberian riversides: from the Cis-Urals steppe and Akmola Area [Gromov, 2011; Marusik, Omelko, 2014; present data] to eastern Mongolia and central China [Ovtsharenko et al., 1992; Song et al., 1999; Marusik, Logunov, 1999, 2006], southward to Nepal [Ovtsharenko et al., 1992], northward to South Siberia (the Altai, Tuva, Buryatia, Khakassia, Transbaikalia) [Ovtsharenko et al., 1992; Marusik, Logunov, 1995: as G. glandifera, 2009; Logunov et al., 1998; Marusik et al., 2000; Danilov, 2008; Azarkina, Trilikauskas, 2013; Fomichev, 2015], with northern isolated populations in Tobolsk (West Siberia) [Esyunin, Stepina, 2014] and central Yakutia [Marusik et al., 1993].

\section{Haplodrassus bohemicus Miller et Buchar, 1977}

MATERIAL. Russia, Orenburg Area: $1+$ (PSU-7578), Svetlyi Distr., 'Ashchisayskaya Steppe' division of Orenburg Reserve, $50^{\circ} 57^{\prime} 38^{\prime \prime} \mathrm{N}, 61^{\circ} 12^{\prime} 44^{\prime \prime} \mathrm{E}$, saline land, 14-23.VI.2015, SSS.

DISTRIBUTION. West-Palaearctic steppe range: from Greece, Macedonia and Czech Republic throughout the steppe zone of Russian Plain [Kovblyuk et al., 2012; Ponomarev, Lebedeva, 2014] to the steppe Cis-Urals [present data].

\section{Haplodrassus orientalis (L. Koch, 1866)}

Fig. 50.

MATERIAL. Russia, Orenburg Area: $12 \sigma^{\top} \sigma^{7}, 10$ ㅇ (PSU7580), $10 \bigcirc^{7} \sigma^{7}, 10$ 우 (ZMMSU), $5 \sigma^{7} \sigma^{7}, 5$ 우 (MMUE), Orenburg Distr., c. $3 \mathrm{~km}$ NE of Pervomajskij Vil., Donguzskaya Steppe $\left(51^{\circ} 33^{\prime} 14^{\prime \prime} \mathrm{N}, 55^{\circ} 01^{\prime} 37^{\prime \prime} \mathrm{E}\right)$, steppe, 3.X.2007-9.IV.2008, KVO; 24 $0^{7} \sigma^{7}, 29$ OQ (PSU-7657), same locality and habitat, IX.2008IV.2009, KVO; 2 O$^{7} \sigma^{7}$ (PSU-7603), $10^{7}$ (MMUE), Svetlyi Distr., 'Ashchisayskaya Steppe' division of Orenburg Reserve $\left(50^{\circ} 57^{\prime}\right.$ $38^{\prime \prime} \mathrm{N}, 61^{\circ} 12^{\prime} 44^{\prime \prime} \mathrm{E}$ ), pond shore mesophytic vegetation, 21-27.IX. 2015, SSS.

DISTRIBUTION. West-Palaearctic steppe range: Greece [Van Keer et al., 2010: sub H. isaevi; Bosmans et al., 2018], 


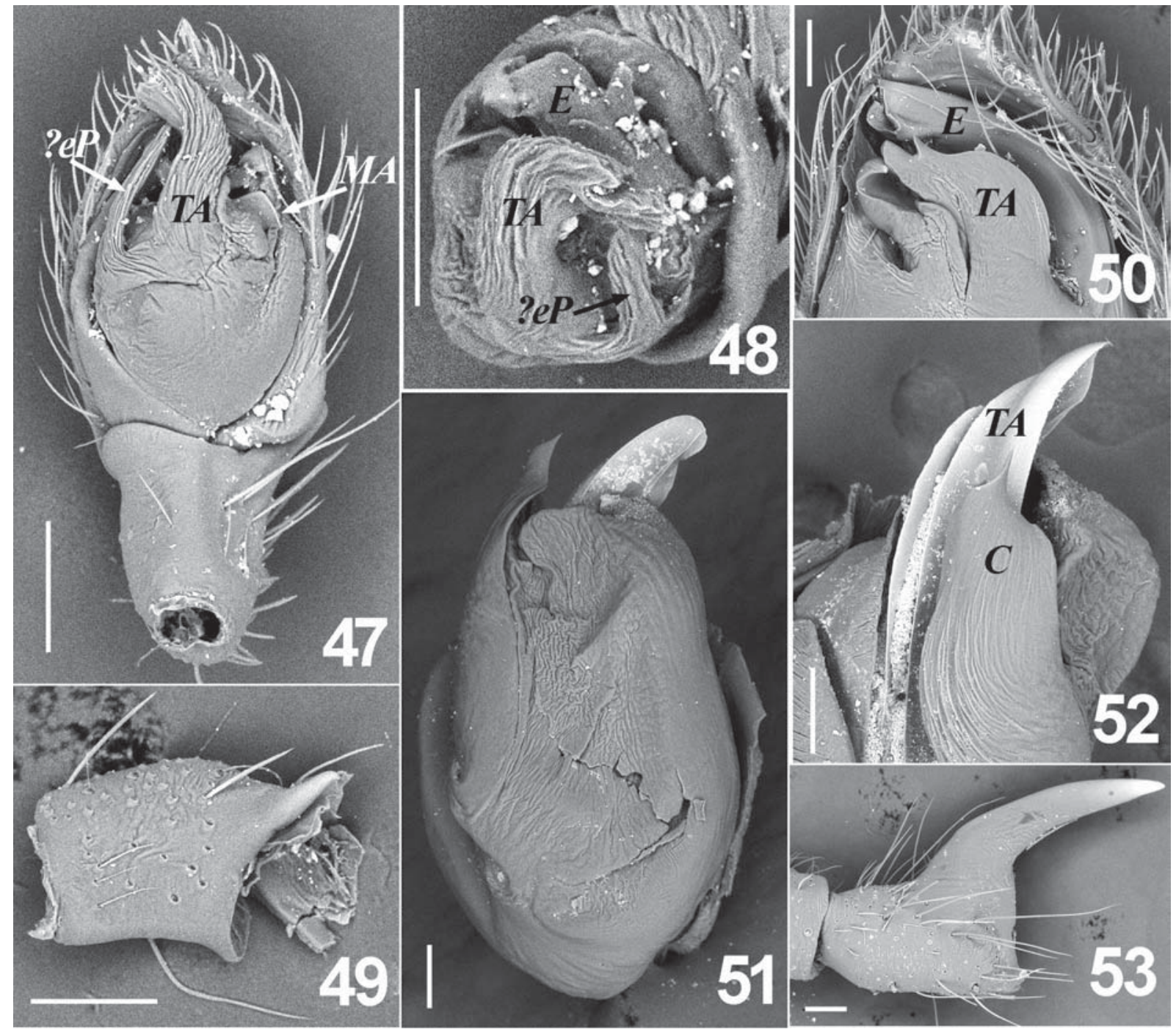

Figs 47-53. Zelotes rufi Efimik, 1997 (47-49), Haplodrassus orientalis (L. Koch, 1866) (50) and Parasyrisca arrabonica Szinetár et Eichardt, 2009 (51-53), scanning electron micrographs: 47 - male palp, ventral view; 48 - embolic division, apical view; 49, 53 — tibia of male palp, lateral and dorsal view, respectively; 50, 52 - apical part of bulbus, ventral and lateral view, respectively; 51 - bulbus, ventral view. Abbreviations: $C$ - conductor of male palp; $E$ - embolus; ? $e P$ — projection of ?embolic base; $M A$ - median apophysis; $T A$ - terminal apophysis. Scale bars: $0.1 \mathrm{~mm}$.

Рис. 47-53. Zelotes rufi Efimik, 1997 (47-49), Haplodrassus orientalis (L. Koch, 1866) (50) и Parasyrisca arrabonica Szinetor et Eichardt, 2009 (51-53), сканирующие электронные микрофотографии: 47 — пальпа, снизу; 48 - эмболюсный отдел, спереди; 49, 53 - голень пальпа самца, соответственно, сбоку и сверху; 50, 52 - верхняя часть бульбуса, соответственно, снизу и сбоку; 51 бульбус, снизу. Сокращения: $C$ - кондуктор; $E-$ эмболюс; ? $P P$ - отросток ?основания эмболюса; $M A-$ срединный отросток; $T A$ - терминальный отросток. Масштаб: 0,1 мм.

the Crimea [Kovblyuk et al., 2012: sub H. isaevi], south regions of Russian Plain (Rostov and Volgograd Areas) [Ponomarev, Tsvetkov 2006; Kovblyuk et al., 2012; Ponomarev, Khnykin, 2013: all sub H. isaevi], West Kazakhstan and Kostanay Areas of Kazakhstan [Piterkina, Ovtsharenko 2007; Ponomarev, Bragina, 2014: all sub H. isaevi], the steppe Cis-Urals [present data].

Micaria bosmansi Kovblyuk et Nadolny, 2008

MATERIAL. Russia, Orenburg Area: 2 우 (PSU-7600), Svetlyi Distr., 'Ashchisayskaya Steppe' division of Orenburg Reserve $\left(50^{\circ} 57^{\prime} 38^{\prime \prime} \mathrm{N}, 61^{\circ} 12^{\prime} 44^{\prime \prime} \mathrm{E}\right)$, steppe, 3-5.V.2015, S.V. Dedyukhin; 1 ( (MMUE), same locality, pond shore mesophytic vegetation, $1-$ 8.VII.2015, SSS; 1 O7, 1 क (PSU-7601), same locality, sand drift near steppe pond, 26.VI.2017, ESL.

DISTRIBUTION. West Palaearctic steppe range: from eastern Ukraine, the Crimea and Turkey [Kovblyuk, Nadolny, 2008; Polchaninova, Prokopenko, 2015; Demir et al., 2015], throughout south regions of Russian Plain (Volgograd and Rostov Areas) [Ponomarev, Dvadnenko, 2012; Ponomarev, Khnykina, 2013] to the steppe trans-Urals [present data]. 

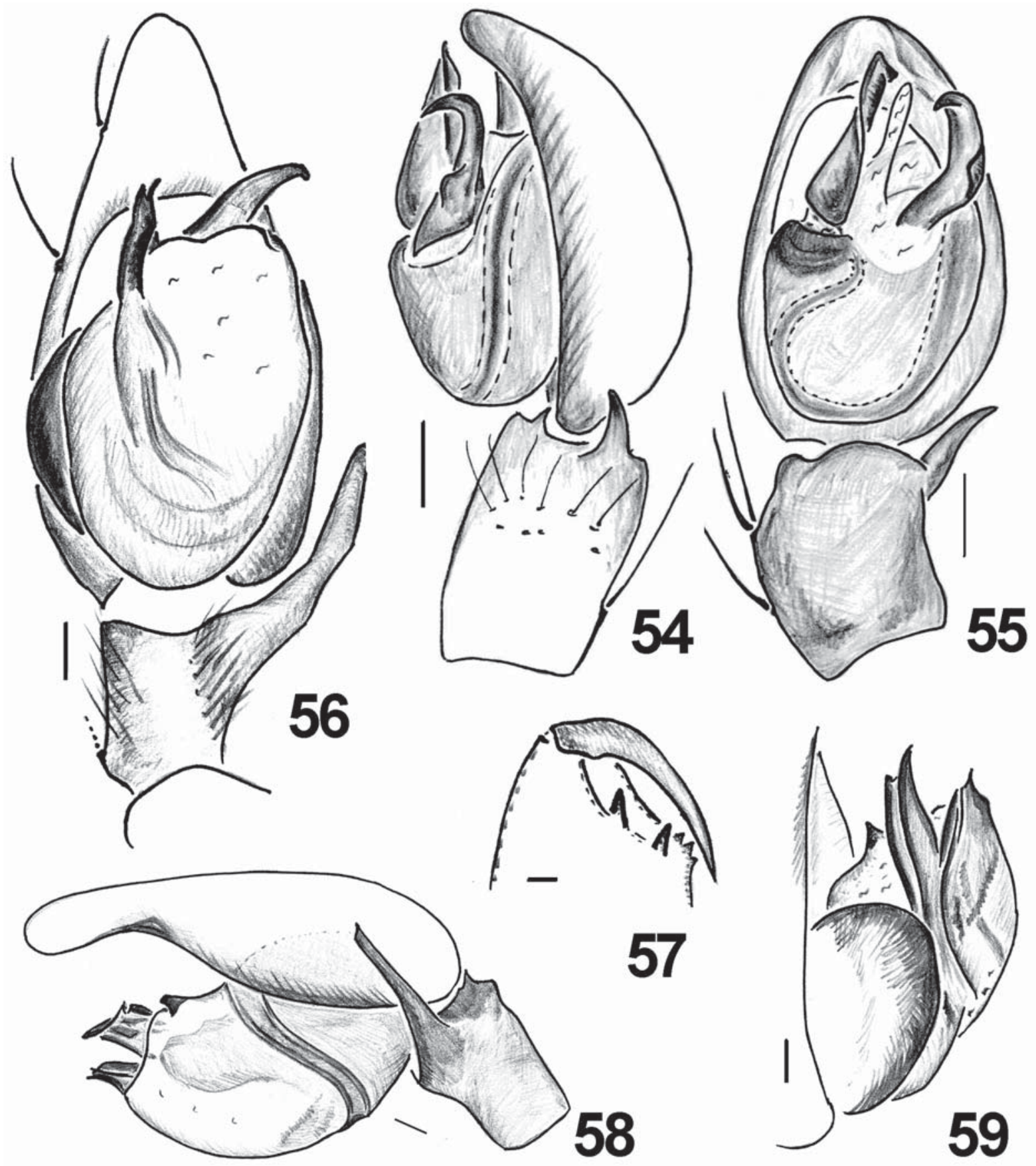

Figs 54-59. Talanites mikhailovi Platnick et Ovtsharenko, 1991 (54-55) and Parasyrisca arrabonica Szinetár et Eichardt, 2009 (5659): 54-57 - male palp, ventral and lateral view; 58 - tip of chelicerae, backside; 59 - bulbus of male palp, prolateral view. Scale bars: $0.1 \mathrm{~mm}$.

Рис. 54-59. Talanites mikhailovi Platnick et Ovtsharenko, 1991 (54-55) и Parasyrisca arrabonica Szinetбr et Eichardt, 2009 (5659): 54-57 - пальпа, снизу и сбоку; 58 - вершина хелицеры, изнутри; 59 - бульбус, сбоку и спереди. Масштаб: 0,1 мм.

Parasyrisca arrabonica Szinetár et Eichardt, 2009 Figs 51-53, 56-59.

MATERIAL. Russia, Orenburg Area: $1 \sigma^{7}$ (PSU-7602), Svetlyi Distr., 'Ashchisayskaya Steppe' division of Orenburg Reserve $\left(50^{\circ} 57^{\prime} 38^{\prime \prime} \mathrm{N}, 61^{\circ} 12^{\prime} 44^{\prime \prime} \mathrm{E}\right)$, saline land, 21-27.IX.2015, SSS.
REMARKS. The species is described from Hungary, where it inhabitants "the calciferous open sand steppes (coenologic name Festucetum vaginatae danubiale)" [Szinetár et al., 2009: 204]. P. arrabonica belongs to the guseripli species group [Fomichev et al., 2018] containing four species. This group has a West-Palaearctic distribution, extend- 
ing from eastern Europe to western China along the steppe zone [Fomichev et al., 2018: map 2].

DISTRIBUTION. West Palaearctic steppe range: from East Europe (Hungary) to the steppe Cis-Urals.

\section{Talanites mikhailovi Platnick et Ovtsharenko, 1991 Figs 54-55.}

MATERIAL. Russia, Orenburg Area: $20^{\top} O^{\top}$ (PSU-4309), Orenburg Distr., c. $3 \mathrm{~km} \mathrm{NE}$ of Pervomajskij Vil., Donguzskaya Steppe $\left(51^{\circ} 33^{\prime} 14^{\prime \prime} \mathrm{N}, 55^{\circ} 01^{\prime} 37^{\prime \prime} \mathrm{E}\right)$, steppe, 20.V-4.VI.2007, KVO Kazakhstan, East-Kazakhstan Area: $1 O^{7}$ (ISEA), Tarbagatai Mts, north-western Manrak Mt. Range, Tayzhuzgen River, 6.IX. 1997, R. Dudko, ZVK

DISTRIBUTION. Kazakhstan steppe range: northern Kazakhstan [Platnick, Ovtsharenko, 1991; Gromov, 2011; Ponomarev, Bragina, 2014; present data] and the steppe Cis-Urals [present data].

Acknowledgments. The authors are grateful to the staff of the Orenburg State Reserve for their help with the organization of fieldworks: viz., R.T. Bakirova, O.V. Soroka, I.I. Raseyikin, V.A. Arzhanukhin. We are also obliged to G.Sh. Farzalieva (Perm State University, Perm, Russia) and A.V. Grischenko (Zoological Museum of the Perm State University, Perm, Russia) for producing digital photographs and SEM micrographs, respectively. Our cordial thanks go to two anonymous referees for constructive commenting on the ms helping us to improve it. Special thanks go to Dmitri V. Logunov (Manchester Museum, UK) for commenting on the ms and for editing the English of the final draft. This study was supported by the State Contract of the Institute of Plant and Animal Ecology, UB RAS (project AAAA-A19119031890085-3).

\section{References}

Abdurakhmanov G.M., Ponomarev A.V., Alieva S.V. 2012. [Spider (Arachnida: Aranei) of the Dagestan: species composition, distribution]. Makhachkala: Dagestan SPU Press. 220 p. [In Russian]

Azarkina G.N., Trilikauskas L.A. 2013. Spider fauna (Aranei) of the Russian Altai, part II: families Gnaphosidae, Hahniidae, Linyphiidae, Liocranidae and Lycosidae // Eurasian Entomological Journal. Vol.12. No.1. P.51-67.

Azarkina G.N., Lyubechanskii I.I., Trilikauskas L.A., Dudko R.Yu., Bespalov A.N., Mordkovich V.G. 2018. A check-list and zoogeographic analysis of the spider fauna (Arachnida: Aranei) of Novosibirsk Area (West Siberia, Russia) // Arthropoda Selecta. Vol.27. No.1. P.73-93.

Bosmans R. 2013. On the Gnaphosid and Lycosid spiders described by L. Giltay from the Balkans (Araneae : Gnaphosidae : Lycosidae) // Bulletin de la Société royale belge. Vol.149. P.179-184.

Bosmans R., Kherbouche-Abrous O., Benhalima S., Hervé C. 2018 The genus Haplodrassus Chamberlin, 1922 in the Mediterranean and the Maghreb in particular (Araneae: Gnaphosidae) // Zootaxa. Vol.4451. No.1. P.1-67.

Chatzaki M. 2018. On the ground spider genera Marjanus gen. n., Lasophorus gen. n. and Turkozelotes Kovblyuk \& Seyyar, 2009 (Araneae: Gnaphosidae) from Greece // Zootaxa. Vol.4392. No.3. P.521-545.

Chatzaki M., Russell-Smith A. 2017. New species and new records of ground spiders (Araneae: Gnaphosidae) from Cyprus // Zootaxa. Vol.4329. No.3. P.237-255.

Chatzopoulou E., Chatzaki M. 2009. Taxonomic review of some Drassodes species from Greece and other east Mediterranean countries (Araneae: Gnaphosidae) // Contributions to Natural History. Vol.12. P.349-359.
Danilov S.N. 2008. [Catalogue of the spider (Arachnida, Aranei) of the Transbaikal]. Ulan-Ude. 108 p. [In Russian]

Demir H., Seyyar O., Türker H., Koçyiðit H.O., Öner H. 2015. The spider fauna of Melendiz Mountains, Nigde, Turkey // Serket. Vol.14. No.3. P.146-166.

Eskov K.Yu., Marusik Yu.M. 1995. On the spiders from Saur Mt. range, eastern Kazakhstan (Arachnida: Araneae) // Beiträge zur Araneologie. Bd.4 (für 1994). P.55-94.

Esyunin S.L., Efimik V.E. 1997. Remarks on the Ural Spider fauna, 6. New data on the taxonomy and faunistics of gnaphosid spiders of the South Urals (Arachnida Aranei Gnaphosidae) // Arthropoda Selecta. Vol.5 (for 1996). No.3/4. P.105-111.

Esyunin S.L., Stepina A.S. 2014. [The fauna and biotopic distribution of the spiders (Aranei) in the southern taiga subzone of the West Siberia] // Bulletin of Perm University. Biology. No.4. P.24-54. [in Russian].

Esyunin S.L., Tuneva T.K. 2002. A review of the family Gnaphosidae in the fauna of the Urals (Aranei), 1. Genera Drassodes Westring, 1851 and Sidydrassus gen.n. // Arthropoda Selecta. Vol.10 (for 2001). No.2. P.169-180.

FitzPatrick M.J. 2005. Three new species of zelotine spiders from Africa (Araneae: Gnaphosidae) // Arnoldia Zimbabwe. Vol.10. No.23. P.235-241.

Fomichev A.A. 2015. On the spider fauna (Arachnida: Aranei) of the Altai Republic (Russia) // Acta Arachnologica. Vol.64. No.2. P.63-70.

Fomichev A.A., Marusik Yu.M., Sidorov V.V. 2018. A survey of East Palaearctic Gnaphosidae (Aranei). 9. New data on the Parasyrisca potanini-group from Central Asia // Arthropoda Selecta. Vol.27. No.2. P.155-168.

Grimm U. 1985. Die Gnaphosidae Mitteleuropas (Arachnida, Araneae) // Abhandlungen des Naturwissenschaftlichen Vereins in Hamburg. Bd.26. S.1-318.

Gromov A.V. 2011. [The interesting records of spiders (Arachnida: Araneae) from central Kazakhstan] // Zoologicheskie issledovaniya za 20 let nezavisimosti respubliki Kazakhstan. Almaty. P.70-75 [in Russian].

Hu J.L., Wu W.G. 1989. [Spiders from agricultural regions of Xinjiang Uygur Autonomous Region, China]. Jinan: Shandong University Publishing House. 435 p. [In Chinese]

Kovblyuk M.M. 2003. The spider genus Drassyllus Chamberlin, 1922 in the Crimean fauna, with description of a new species (Aranei: Gnaphosidae) // Arthropoda Selecta. Vol.12. No.1. P.23-28.

Kovblyuk M.M. 2005. The spider genus Gnaphosa Latreille, 1804 in the Crimea (Aranei: Gnaphosidae) // Arthropoda Selecta. Vol.14. No.2. P.133-152.

Kovblyuk M.M. 2008. Spiders of genus Drassodes (Aranei, Gnaphosidae) of the Crimean fauna // Vestnik zoologii. Vol.42. No.1. P.11-24 [in Russian].

Kovblyuk M.M., Kastrygina Z.A. 2015. Updated catalogue of the spiders (Arachnida, Aranei) of the Crimea // Ukrainska Entomofaunistyka. Vol.6. No.2. P.1-81.

Kovblyuk M.M., Kastrygina Z.A., Omelko M.M. 2012. A review of the spider genus Haplodrassus Chamberlin, 1922 in the Crimea (Ukraine) and adjacent areas (Araneae, Gnaphosidae) // ZooKeys. Vol.205. P.59-89.

Kovblyuk M.M., Nadolny A.A. 2008. The spider genus Micaria Westring, 1851 in the Crimea (Aranei: Gnaphosidae) // Arthropoda Selecta. Vol.16. No.4. P.215-236.

Kovblyuk M.M., Seyyar O., Demir H., Topçu A. 2009. New taxonomic and faunistic data on the gnaphosid spiders of Turkey (Aranei: Gnaphosidae) // Arthropoda Selecta. Vol.18. No.3/4. P.169-187.

Levy G. 1998. The ground-spider genera Setaphis, Trachyzelotes, Zelotes, and Drassyllus (Araneae: Gnaphosidae) in Israel // Israel Journal of Zoology. Vol.44. P.93-158.

Levy G. 2004. Spiders of the genera Drassodes and Haplodrassus (Araneae, Gnaphosidae) from Israel // Israel Journal of Zoology. Vol.50. P.1-37.

Lissner J. 2018. A new pirate spider of the genus Ero (Araneae: Mimetidae) from the Canary Islands, with contributions on 
other Palaearctic species // Arachnology. Vol.17. No.8. P.410418.

Logunov D.V., Marusik Yu.M., Koponen S. 1998. A check-list of the spiders in Tuva, South Siberia with analysis of their habitat distribution (Arachnida: Araneae) // Berichte des naturwissenschaftlichen-medizinischen Verein Innsbruck. Bd.85. P.125159 .

Loksa I. 1965. Ergebnisse der zoologischen Forschungen von Dr. Z. Kaszab in der Mongolei. Araneae // Reichenbachia. Bd.7. S.1-32.

Marusik Yu.M., Eskov K.Yu., Koponen S., Vinokurov N.N. 1993. A check-list of the spiders (Aranei) of Yakutia, Siberia // Arthropoda Selecta. Vol.2. No.2. P.63-79.

Marusik Yu.M., Fritzén N.R., Song D.X. 2007. On spiders (Aranei) collected in central Xinjiang, China // Arthropoda Selecta. Vol.15 (for 2006). No.3. P.259-276.

Marusik Yu.M., Logunov D.V. 1995. Gnaphosid spiders from Tuva and adjacent territories, Russia // Beiträge zur Araneologie. Bd.4 (für 1994). P.177-210.

Marusik Yu.M., Logunov D.V. 1999. On the spiders (Aranei) collected in central Mongolia during a joint American-Mongolian-Russian expedition in 1997 // Arthropoda Selecta. Vol.7 (for 1998). No.3. P.233-254.

Marusik Yu.M., Logunov D.V. 2006. On the spiders collected in Mongolia by Dr. Z. Kaszab during expeditions in 1966-1968 (Arachnida, Aranei (excluding Lycosidae)) // Arthropoda Selecta. Vol.15. No.1. P.39-57.

Marusik Yu.M., Logunov D.V. 2009. New faunistic records of spiders collected from the mountain Altai (Arachnida: Aranei) // Arthropoda Selecta. Vol.18. No.3/4. P. 145-152.

Marusik Yu.M., Logunov D.V. 2011. New faunistic records of spiders from east Kazakhstan (Arachnida: Aranei) // Arthropoda Selecta. Vol.20. No.1. P. 57-63.

Marusik Yu.M., Logunov D.V., Koponen S. 2000. Spiders of Tuva, South Siberia. Magadan: IBPN FEB RAS. 252 p.

Marusik Yu.M., Omelko M.M. 2014. A survey of East Palaearctic Gnaphosidae (Araneae). 3. On new and poorly known Gnaphosa Latreille, 1804 // Zootaxa. Vol.3894. No.1. P.10-32.

Milano F., Mammola S., Rollard C., Leccia M.-F., Isaia M. 2019 An inventory of the spider species of Barcelonnette (France), with taxonomic notes on Piniphantes agnellus n. comb. (Araneae, Linyphiidae) // Zoosystema. Vol.41. No.4. P.29-58.

Miller F. 1943. Neue Spinnen aus der Serpentinsteppe bei Mohelno in Mähren // Entomologické Listy, Brno. Nr.6. S.11-29.

Miller F. 1967. Studien über die Kopulationsorgane der Spinnengattung Zelotes, Micaria, Robertus und Dipoena nebst Beschreibung einiger neuen oder unvollkommen bekannten Spinnenarten // Pøírodovidné práce ústavù Ėeskoslovenské Akademie Vìd v Brnì (N.S.). Bd.1. S.251-298.

Namaghi H.S., Safari A., Entezari E., Zamani A. 2016. New faunistic records of spiders (Araneae) from Razavi Khorasan Province, Iran // Zoology and Ecology. Vol.26. No.1. P.18-21.

Nentwig W, Blick T, Gloor D, Hänggi A, Kropf C. 2018. Spinnen Europas, online at: https://www.araneae.nmbe.ch, version 12.2018 (accessed on December $20^{\text {th }}, 2018$ ); doi: $10.24436 / 1$.

Ovtsharenko V.I., Platnick N.I., Song D.-X. 1992. A review of the North Asian ground spiders of the genus Gnaphosa (Araneae, Gnaphosidae) // Bulletin of the American Museum of Natural History. No.212. P.1-88.

Piterkina T.V. 2009. Spiders (Arachnida, Araneae) of the Dzhanybek Research Station, West Kazakhstan: a local fauna in a biogeographical aspect // Golovatch S.I., Makarova O.L., Babenko A.B. \& Penev L.D. (eds.) Species and Communities in Extreme Environments. Festschrift towards the 75th Anniversary and a Laudatio in Honour of Academician Yuri Ivanovich Chernov. Sofia-Moscow: Pensoft Publishers \& KMK Scientific Press. P.335-356.

Piterkina T.V., Ovtsharenko V.I. 2007. [Interesting findings of spiders of the families Gnaphosidae and Liocranidae (Aranei) from semi-desert of the northern Caspian lowland] // Zoologicheskiy Zhurnal. Vol.86. No.12. P.1425-1432 [in Russian].

Platnick N.I., Murphy J.A. 1984. A revision of the spider genera Trachyzelotes and Urozelotes (Araneae, Gnaphosidae) // American Museum Novitates. No.2792. P.1-30.
Platnick N.I., Ovtsharenko V.I. 1991. On Eurasian and American Talanites (Araneae, Gnaphosidae) // Journal of Arachnology. Vol.19. P.115-121.

Platnick N.I., Shadab M.U. 1976. A revision of the spider genera Drassodes and Tivodrassus (Araneae, Gnaphosidae) in North America // American Museum Novitates. No.2593. P.1-29.

Platnick N.I., Shadab M.U. 1982. A revision of the American spiders of the genus Drassyllus (Araneae, Gnaphosidae) // Bulletin of the American Museum of Natural History Vol.173. P.1-97.

Platnick N.I., Shadab M.U. 1983. A revision of the American spiders of the genus Zelotes (Araneae, Gnaphosidae) // Bulletin of the American Museum of Natural History. Vol.174. P.97-192.

Polchaninova N.Yu., Prokopenko E.V. 2015. Catalogue of the spiders (Arachnida, Aranei) of Left-Bank Ukraine // Arthropoda Selecta. Supplement No.2. Moscow: KMK Scientific Press. $268 \mathrm{p}$.

Ponomarev A.V., Abdurakhmanov G.M. 2014. [Spiders (Aranei) of the coast and islands of the northern part of the Caspian Sea] // Yugh Rossii: ekologiya, razvitie. No.1. P.76-121 [in Russian].

Ponomarev A.V., Abdurakhmanov G.M., Alieva S.V., Dvadnenko K.V. 2011. [Spiders (Arachnida: Aranei) of coastal and island territories of northern Dagestan] // Yugh Rossii: ekologiya, razvitie. No.4. P.126-143 [in Russian].

Ponomarev A.V., Belosludtsev E.A., Dvadnenko K.V. 2008. [Spiders (Aranei) of the Lower Volga Region (Astrakhan and Volgograd Areas of Russia) with the description of new taxa] // Caucasian entomological Bulletin. Vol.4. No.2. P.163-185 [in Russian].

Ponomarev A.V., Bragina T.M. 2014. [Preliminary data on spiders fauna (Aranei) of protected areas in Kostanay Region (Kazakhstan)] // Yugh Rossii: ekologiya, razvitie. No.4. P.46-57 [in Russian]

Ponomarev A.V., Dvadnenko K.V. 2012. [Remarks on taxonomy and fauna of the spiders (Aranei) of the south of Russia and eastern Kazakhstan] // Yugh Rossii: ekologiya, razvitie. No.4. P.42-53 [in Russian].

Ponomarev A.V., Dvadnenko K.V. 2013. [Notes on the spider fauna (Aranei) of the South-East of the Russian Plain and Caucasus with the description of a new species of the genus Haplodrassus Chamberlin, 1922 (Gnaphosidae)] // Vestnik Yuzhnogo nauchnogo tsentra. Vol.9. No.2. P.47-56 [in Russian].

Ponomarev A.V., Khnykin A.S. 2013. [Spiders (Aranei) of Volgograd City and its adjacensis] // Yugh Rossii: ekologiya, razvitie. No.4. P.109-136 [in Russian].

Ponomarev A.V., Lebedeva N.V. 2014. Spiders (Aranei) and some of their cenotic links in gully forests of the lower Don River // Arid Ecosystems. Vol.4. No.2. P.107-118.

Ponomarev A.V., Mikhailov K.G. 2007. [The addition to spider fauna (Aranei) of the Russian Caucasus] // Trudy Yuzhnogo nauchnogo tsentra RAN. T.III. Biodiversity and transformation of the mountain ecosystem of the Caucasus. Rostov-naDonu: SSC RAS Press. (2006). P.130-151 [in Russian].

Ponomarev A.V., Prokopenko E.V., Ivliev P.P., Shmatko V.Y. 2016. Spiders (Aranei) of the coast of Taganrog Bay (the Sea of Azov) and the Don River delta // Caucasian Entomological Bulletin. Vol.12. No.1. P.3-28 [in Russian].

Ponomarev A.V., Tsvetkov A.S. 2004. [The generalized data on spiders (Aranei) of the Nature Research "Rostovski"] // Trudy Gosudarstvennogo Zapovednika "Rostovskii”. Vol.3. P.84-104 [in Russian].

Ponomarev A.V., Tsvetkov A.S. 2006. [New and rare spiders of family Gnaphosidae (Aranei) from a southeast of Europe] // Caucasian Entomological Bulletin. No.2. P.5-13 [in Russian].

Savelyeva L.G. 1972. [New species of Gnaphosidae (Aranei) from the East-Kazakhstan Distr.] // Zoologicheskiy Zhurnal. Vol.51. No.8. P.1238-1241 [in Russian].

Schenkel E. 1936. Schwedisch-chinesische wissenschaftliche Expedition nach den nordwestlichen Provinzen Chinas, unter Leitung von Dr Sven Hedin und Prof. Sü Ping-chang. Araneae 
gesammelt vom schwedischen Artz der Exped // Arkiv för Zoologi. Bd.29A. H.1. S.1-314.

Senglet A. 2011. New species in the Zelotes tenuis-group and new or little known species in other Zelotes groups (Gnaphosidae, Araneae) // Revue suisse de Zoologie. T.118. P.513-559.

Senglet A. 2012. Civizelotes new genus, and other new or little known Zelotinae (Araneae, Gnaphosidae) // Revue suisse de Zoologie. T.119. No.4. P.501-528.

Seo B.K. 2002. Two species of gnaphosid spider (Araneae)// Journal of the Institute of Natural Sciences, Keimyung University. Vol.21. No.2. P.57-60.

Seo B.K. 2017. A new species and three new records of the families Gnaphosidae and Clubionidae (Araneae) from Korea // Korean Journal of Environmental Biology. Vol.35. No.2. P.191-197.

Song D.X., Zhu M.S., Chen J. 1999. The Spiders of China. Shijiazhuang: Hebei University of Science and Techology Publishing House. $640 \mathrm{p}$.

Song D.X., Zhu M.S., Zhang F. 2004. Fauna Sinica: Invertebrata Vol.39: Arachnida: Araneae: Gnaphosidae. Beijing: Science Press. 362 p. [In Chinese]

Szinetár C., Eichardt J., Szüts, T. 2009. The first lowland species of the Holarctic alpine ground spider genus Parasyrisca (Araneae, Gnaphosidae) from Hungary // ZooKeys. Vol.16. P.197208.

Thaler K., Noflatscher M.-T. 1990. Neue und bemerkenswerte Spinnenfunde in Südtirol (Arachnida: Aranei) // Veröffentlichungen des Museum Ferdinandeum in Innsbruck. Bd.69. S.169-190.

Tullgren A. 1946. Svenska spindelfauna: 3. Egentliga spindlar. Araneae. Fam. 5-7. Clubionidae, Zoridae och Gnaphosidae. Stockholm: Entomologiska Föreningen.. 141 p.

Tuneva T.K. 2003. [Urozelotes trifidus sp.n. - a new species of gnaphosid spiders (Aranei, Gnaphosidae) of steppe zone of the south Urals] // Eurasian Entomological Journal. Vol.2. No.2. P.95-96 [in Russian].

Tuneva T.K. 2004. A contribution to the gnaphosid spider fauna (Araneae: Gnaphosidae) of east Kazakhstan // Logunov D.V., D. Penney (eds.). European Arachnology 2003. Proceedings of the 21st European Colloquium of Arachnology, St.-Petersburg, 4-9 August 2003 // Arthropoda Selecta. Special Issue 1. P.319332
Tuneva T.K. 2007. Review of the family Gnaphosidae on the Ural fauna (Aranei), 5. Genera Micaria Westring, 1851 and Arboricaria Bosmans, 2000 // Arthropoda Selecta. Vol.15 (for 2006). No.3. P.229-250.

Tuneva T.K., Esyunin S.L. 2002. A review of the family Gnaphosidae on the fauna of the Urals (Aranei), 2. New and rare genera // Arthropoda Selecta. Vol.10 (for 2001). No.3. P.217224.

Tuneva T.K., Esyunin S.L. 2003a. A review of the family Gnaphosidae in the fauna of the Urals (Aranei), 3. New species and new records, chiefly from the South Urals // Arthropoda Selecta. Vol.11 (for 2002). No.3. P.223-234.

Tuneva T.K., Esyunin S.L. 2003b. A review of the family Gnaphosidae in the fauna of the Urals (Aranei), 4. The first record of Gnaphosa tigrina Simon, 1878 and remarks on two species from the rufula group // Arthropoda Selecta. Vol.11 (for 2002). No.4. P.277-281.

Tuneva T.K., Esyunin S.L. 2009. Diversity of fauna and geographic distribution of Gnaphosidae spiders (Aranei) in the Urals // Entomological Review. Vol.89. No.8. P.1001-1012.

Tuneva T.K., Esyunin S.L. 2012. [Spider (Aranei) fauna of the "Leonovskie gory" range (Chelyabinsk Area)] // Eurasian entomological Journal. Vol. 11. No.4. P.373-377 [in Russian].

Van Keer1 J., Van Keer K., De Koninck H., Ramel G. 2010. The Arachnofauna (Araneae) of Wetland Kerkini (Macedonia-Northern Central Greece) // Acta zoologica bulgarica. Vol.62. No.2. P.141-160.

WSC 2018. World Spider Catalog. Natural History Museum Bern, online at: http://wsc.nmbe.ch, version 19.5 (accessed on December $20^{\text {th }}, 2018$ ); doi: $10.24436 / 2$.

Xu Y.J. 1991. [Studies on the spiders of the family Gnaphosidae from Anhui (Part II)] // Journal of the Huizhou Teachers School. No.1. P.37-41 [in Chinese].

Zamani A., Nikmaghan Z., Allahdadi M., Ghassemzadeh F., Mirshamsi O. 2014. New data on the spider fauna of Iran (Arachnida: Araneae) // Zoology in the Middle East. Vol.60. No.4. P.362-367.

Zhu M.S., Zhang B.S. 2011. Spider Fauna of Henan: Arachnida: Araneae. Beijing: Science Press. 558 p. [In Chinese]

Responsible editor D.V. Logunov 